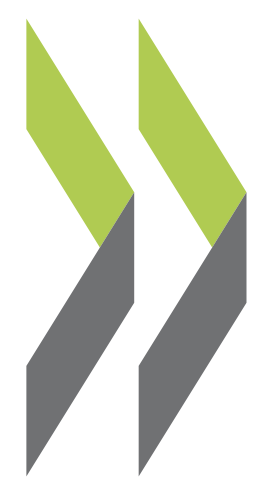

OECD Economics Department Working Papers No. 1006

Debt and Macroeconomic Stability: An Overview of the Literature and Some Empirics

\section{Douglas Sutherland,}

Peter Hoeller 
Organisation de Coopération et de Développement Économiques

Organisation for Economic Co-operation and Development

07-Dec-2012

ECONOMICS DEPARTMENT

English - Or. English

DEBT AND MACROECONOMIC STABILITY: AN OVERVIEW OF THE LITERATURE AND SOME EMPIRICS

ECONOMICS DEPARTMENT WORKING PAPERS No. 1006

By Douglas Sutherland and Peter Hoeller

All Economics Department Working Papers are available through OECD's Internet website at www.oecd.org/eco/Workingpapers

JT03332435

Complete document available on OLIS in its original format

This document and any map included herein are without prejudice to the status of or sovereignty over any territory, to the delimitation of international frontiers and boundaries and to the name of any territory, city or area. 


\section{ABSTRACT/RÉSUMÉ}

\section{Debt and macroeconomic stability: An overview of the literature and some empirics}

How does debt affect macroeconomic stability? The answer to this question has important implications, because both public and private debt levels have reached historic highs across the OECD. While accumulating debt can help smooth real activity, at high levels debt creates weaknesses in corporate, household and government balance sheets. High debt levels can create vulnerabilities, which amplify and transmit macroeconomic and asset price shocks across the economy and internationally. The empirical evidence shows that high debt levels impair the ability of households and enterprises to smooth consumption and investment and of governments to cushion adverse shocks. The empirical evidence also suggests that when private sector debt levels, particularly for households, rise above trend the likelihood of recession increases. Furthermore, when debt levels are high, recessions tend to be more severe.

JEL classification codes: E62; H50; H68; J11

Keywords: Debt; macroeconomic stability; business cycles; recession

$$
* * * * *
$$

\section{Dette et stabilité macroéconomique : Aperçu général des études existantes et faits constatés}

Quels sont les effets de l'endettement sur la stabilité macroéconomique ? La réponse à cette question a des conséquences importantes car les niveaux d'endettement publics et privés atteignent des sommets historiques dans les pays de l'OCDE. S'il est vrai que l'accumulation de dettes peut aider à lisser l'activité réelle, un endettement élevé affaiblit les bilans des entreprises, des ménages et de l'État. Un fort endettement peut être à l'origine de vulnérabilités, qui amplifient et répercutent les chocs macroéconomiques et les variations des prix des actifs dans l'économie et au plan international. L'expérience montre que des niveaux élevés d'endettement limitent la possibilité pour les ménages et les entreprises de lisser leur consommation et leurs investissements et, pour les gouvernements, d'amortir les chocs défavorables. Les données d'observations semblent aussi indiquer que lorsque la dette du secteur privé, en particulier celle des ménages, dépasse la tendance, la probabilité de récession s'accroît. Par ailleurs, lorsque les niveaux d'endettement sont élevés, les récessions sont généralement plus sévères.

Classification JEL : E62 ; H50 ; H68 ; J11

Mots-clés : Dette ; stabilité macroéconomique ; cycles économiques ; récession

\section{(C) OECD (2012)}

You can copy, download or print OECD content for your own use, and you can include excerpts from OECD publications, databases and multimedia products in your own documents, presentations, blogs, websites and teaching materials, provided that suitable acknowledgment of OECD as source and copyright owner is given. All requests for commercial use and translation rights should be submitted to rights@oecd.org. 


\section{TABLE OF CONTENTS}

\section{DEBT AND MACROECONOMIC STABILITY: AN OVERVIEW OF THE LITERATURE AND} SOME EMPIRICS

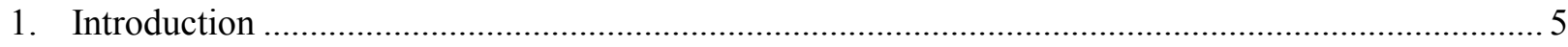

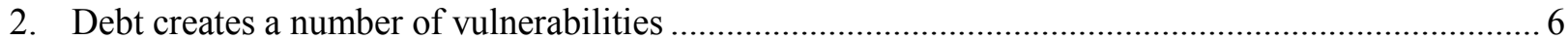

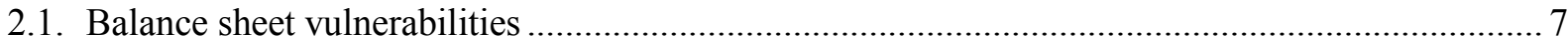

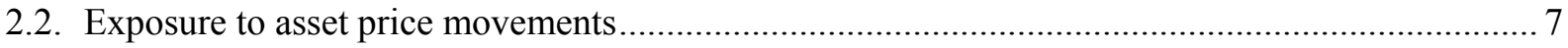

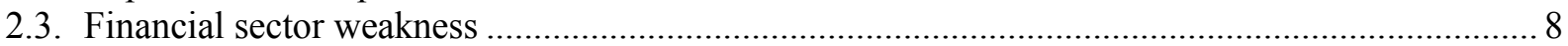

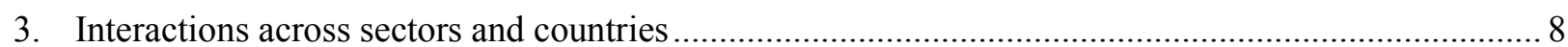

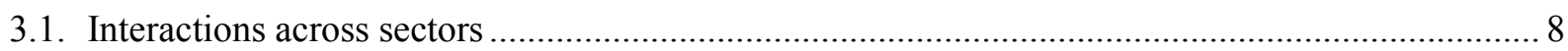

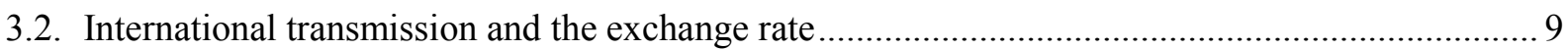

4. The secular rise in indebtedness and its impact on macroeconomic stability................................... 9

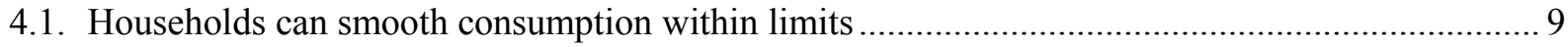

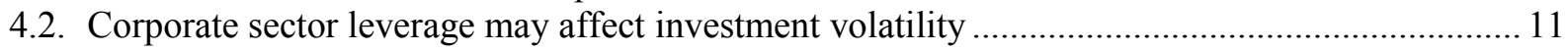

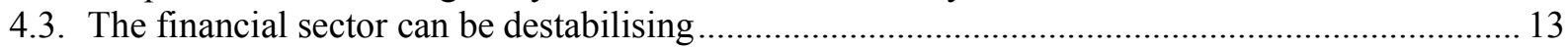

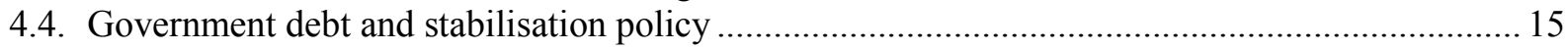

5. The empirical relationship between debt and macroeconomic volatility ......................................... 17

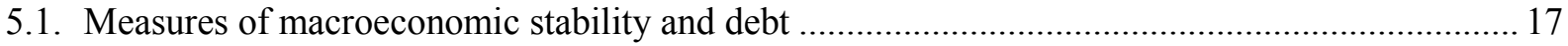

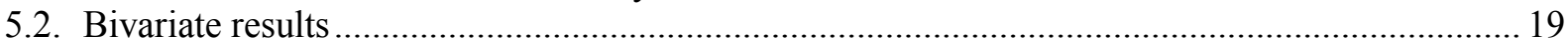

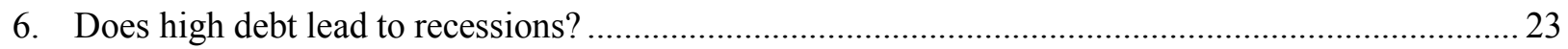

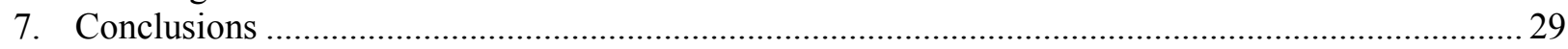

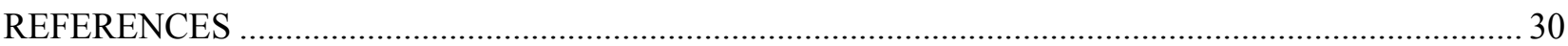

\section{Boxes}

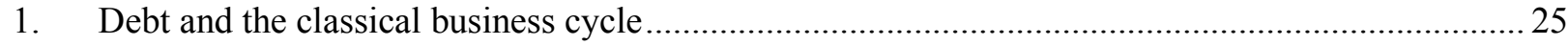

\section{Tables}

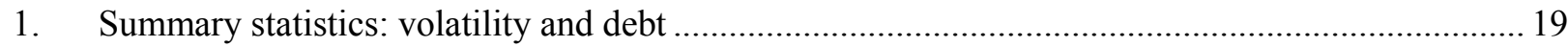

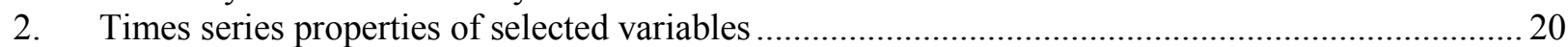

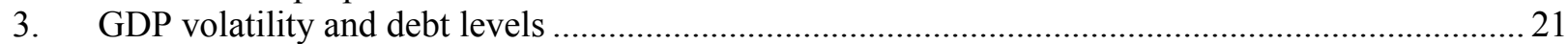

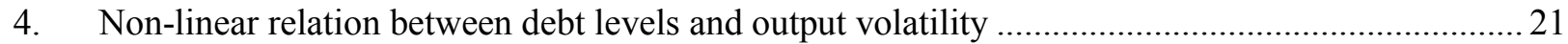

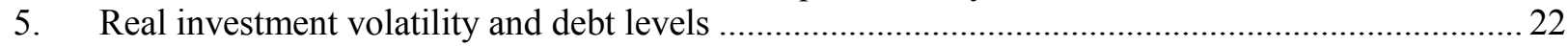

6. Real investment volatility and non-financial sector leverage .................................................. 22

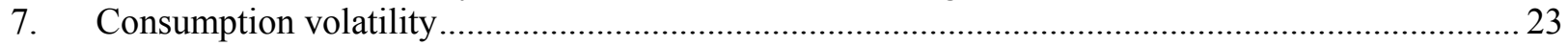

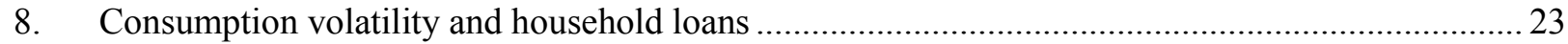

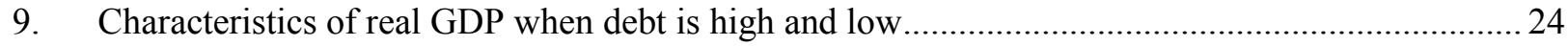

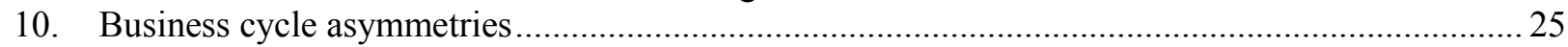

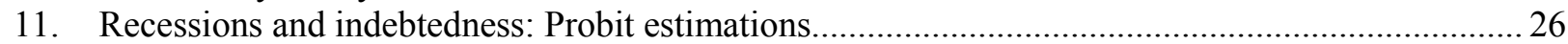

12. Recessions and indebtedness: Probit estimations using a shorter sample ...................................... 28

13. Recessions and indebtedness: Probit estimations using a longer lag .......................................... 28 


\section{Figures}

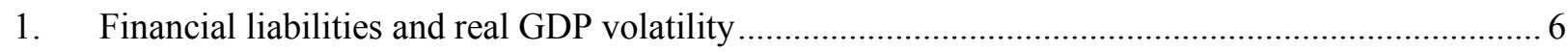

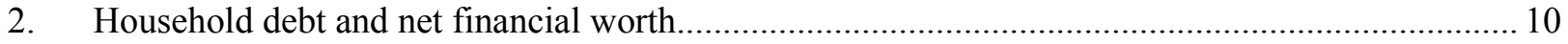

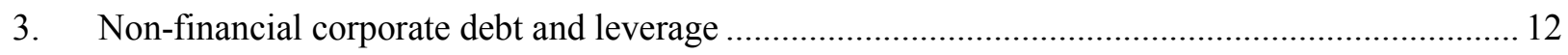

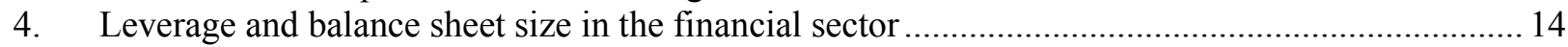

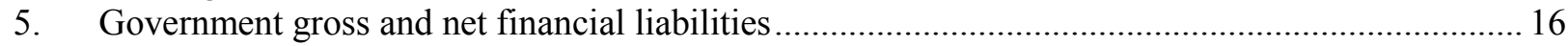

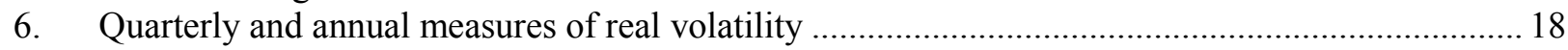

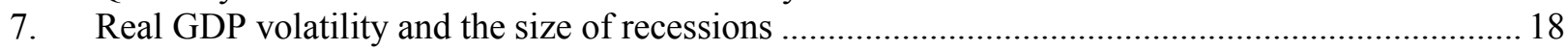

8. The marginal effect of household debt relative to trend on the probability of a recession ................27

9. The predicted probability of recession when household debt relative to trend rises....................... 27 
ECO/WKP(2012)83

\title{
DEBT AND MACROECONOMIC STABILITY: AN OVERVIEW OF THE LITERATURE AND SOME EMPIRICS
}

\author{
by Douglas Sutherland and Peter Hoeller ${ }^{1}$
}

\section{Introduction}

Debt as a share of GDP has surged since the mid-1990s. OECD-wide, average total economy financial liabilities have more-than doubled and gone beyond $1000 \%$ of GDP during the recent crisis (Figure 1). ${ }^{2}$ The build-up was most marked in the financial sector, while household debt also grew rapidly. In comparison, the rise in the financial liabilities of the government sector and of non-financial enterprises was smaller. The size of financial sector liabilities exhibits considerable heterogeneity across countries, being markedly higher in countries which host financial centres. In general, real GDP volatility had been declining until the crisis, but has subsequently increased significantly (Figure 1).

Against this backdrop, this paper reviews the channels through which high debt levels affect macroeconomic stability. High debt levels hinder the ability of households and enterprises to smooth consumption and investment and the ability of governments to cushion adverse shocks can become impaired. Furthermore, elevated debt levels can create vulnerabilities to shocks and can amplify and transmit macroeconomic and asset price shocks throughout the economy and internationally. The empirical section of the paper aims to gauge the relationship between debt levels on aggregate as well as different economic sectors and different measures of macroeconomic volatility, including the assessment of whether high debt levels raise the likelihood of an economy falling into recession.

1. The authors are members of the Economic Department of the OECD. This is one of the background papers for the OECD's project on Debt and Macroeconomic Stability (see Sutherland et al., 2012 for the main paper). This paper is a revised version of a document prepared for a meeting of Working Party No. 1 of the OECD Economic Policy Committee held in October 2012. The authors are indebted to the participants of the meeting as well as Jorgen Elmeskov, Rossana Merola, Jean-Luc Schneider and Volker Ziemann for useful comments and suggestions and to Susan Gascard for excellent editorial support.

2. The choice of measure of financial liabilities or debt can make an important difference. The figure reported is the un-weighted average of non-consolidated total economy financial liabilities (the median is $840 \%$ of GDP). For consolidated accounts, the corresponding figures are just over $1000 \%$ of GDP and $540 \%$ of GDP for the mean and median, respectively. The un-weighted average of debt (gross financial liabilities minus share capital and derivatives) is over $800 \%$ of GDP for non-consolidated accounts and $500 \%$ of GDP for consolidated accounts. 
Figure 1. Financial liabilities and real GDP volatility

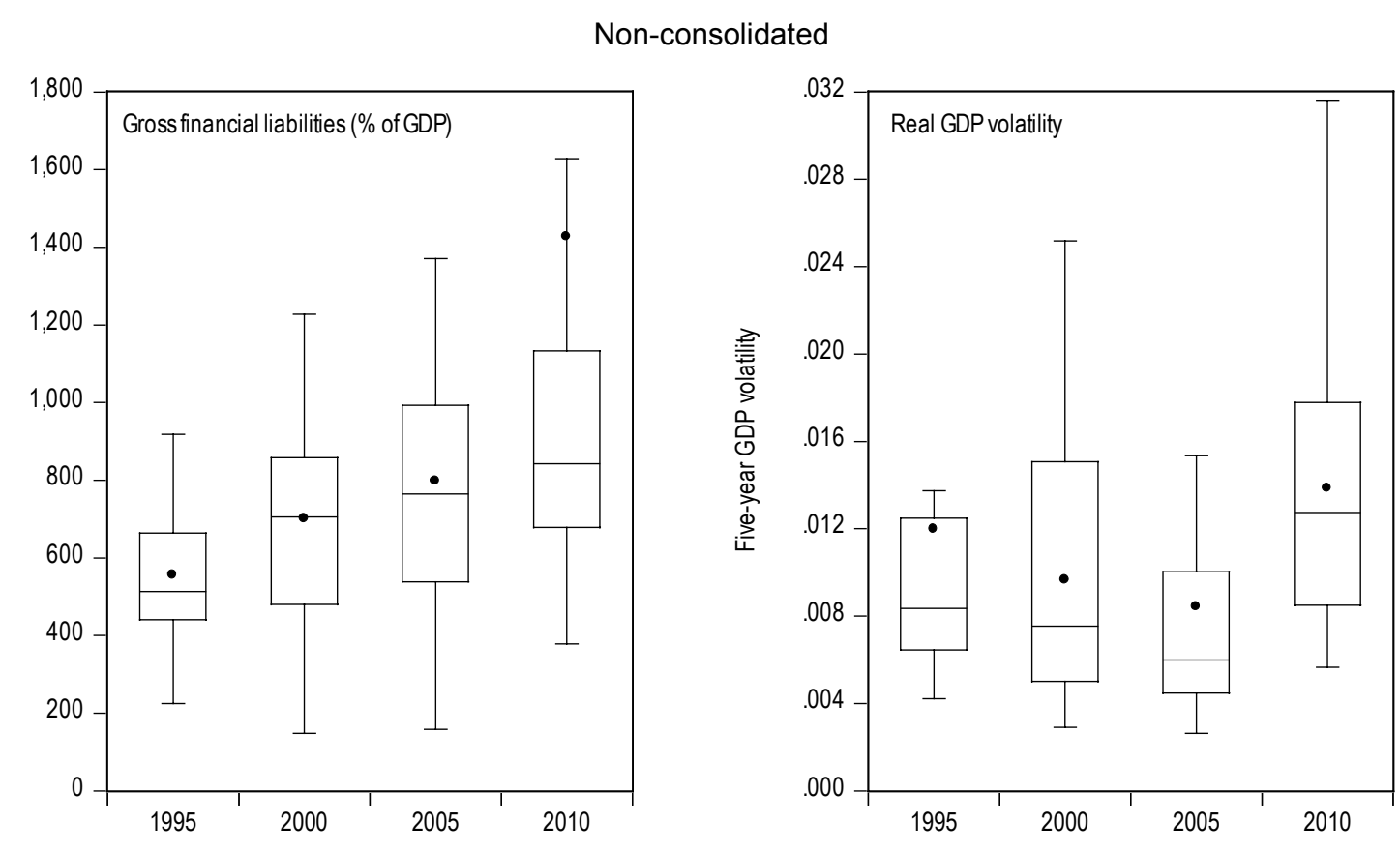

Note: These plots display the box that covers the observations between the $1^{\text {st }}$ and $3^{\text {rd }}$ quartiles, as well as the median (the horizontal bar) and the mean (the point). The whiskers extending from the box give the range that captures the observations which lie within 1.5 times the inter-quartile range from the $1^{\text {st }}$ and $3^{\text {rd }}$ quartiles. Real GDP volatility is the rolling average of the standard deviation of quarterly real GDP growth over 20 quarters. Outliers are excluded from the figures.

Source: OECD National Accounts.

The rest of the paper is structured as follows. The second section discusses the vulnerabilities debt can create and potential links with macroeconomic stability. The third section considers linkages between sectors and across countries. The fourth section documents debt developments for the institutional sectors, reviews reasons why the different sectors hold debt and why indebtedness has gone up and discusses the links between high indebtedness and macroeconomic stability. The fifth section turns to a simple econometric evaluation of the links between debt levels and different measures of macroeconomic volatility. The sixth section considers whether high debt levels are associated with a higher probability of recessions occurring. A final section concludes.

\section{Debt creates a number of vulnerabilities}

Debt or leverage can affect macroeconomic performance through several channels. While some may directly transmit or amplify shocks others undermine the capacity to damp shocks. For example, relatively high debt or leverage may make sectors more sensitive to changes in fundamentals which can induce households or firms to adjust their borrowing, consumption and investment behaviour. Until recently, macroeconomic theory has paid relatively little attention to balance sheets with the exception of considering how high debt levels create macroeconomic vulnerabilities for developing countries. 
ECO/WKP(2012)83

\subsection{Balance sheet vulnerabilities}

Debt tends to create balance sheet vulnerabilities due to mismatches and related problems (Allen et al., 2002). These include:

- Maturity mismatch: with a high level of short-term liabilities, borrowers may face problems with rolling over debt (e.g. liquidity risks) and may be exposed to an interest rate shock.

- Currency mismatch: if liabilities are denominated in foreign currency, borrowers face exposure to liquidity and exchange rate risk. Liquidity problems emerged during this crisis, when non-US banks had dollar funding problems. While exchange rate risk is generally more of a problem for sovereign borrowers in developing countries, households and the corporate sector in developed countries can also be exposed to this risk. Household borrowing is less likely to be hedged against exchange rate risk, as was the case in some central European countries recently.

- Capital structure problems: corporate sectors with higher reliance on debt rather than equity financing may be less able to cope with adverse revenue shocks.

- Solvency problems: these can arise from maturity and currency mismatches, an inadequate capital structure or simply over-borrowing. Furthermore, pronounced bunching of debt may periodically threaten solvency. Thus, while gross debt levels provide some information on vulnerabilities, the debt structure is also important.

When the state of the balance sheet is poor, even quite small changes in the relative attractiveness of different assets can put balance sheets under pressure. As funding dries up, the shock may be particularly felt by marginal borrowers, who can then transmit the shock across sectors. For example, since debt repayments tend to be fixed, an adverse income shock will squeeze the cash flow available for consumption or investment (Jorda et al., 2011). Changes in liquidity constraints at higher levels of leverage can amplify the effect of a shock, particularly if the shock affects credit supply (Barrell et al., 2006).

\subsection{Exposure to asset price movements}

At higher debt levels exposure to asset price movements may become more of a problem for companies, governments and households. Financial accelerator models show how shocks can be amplified, particularly when asset price boom-bust cycles act through the value of collateral, which accentuates cyclical fluctuations and may generate debt-deflation pressures during a downturn. Borrowers that use assets as collateral are limited in their ability to borrow, and hence to invest, if the market value of collateral declines, which may induce deleveraging (Bernanke and Gertler, 1990; Kiyotaki and Moore, 1997). While macroeconomic volatility declined during the "great moderation" asset price cycles had become more volatile (Égert and Sutherland, 2012). In this context, the bursting of an asset price boom combined with a severe recession has important implications for the ability of households and firms to smooth consumption and investment.

At higher levels of debt, a shock to asset prices (e.g. stocks and housing) will have a large effect on net wealth and thus spending. Estimates of the marginal propensity to consume out of household net wealth range between 2 and 8\%, being typically higher in the English-speaking countries (Davis, 2010). Moreover, a collapse in house prices reduces collateral, thereby limiting mortgage equity withdrawal available for consumption smoothing. For government, revenues can quickly lose their buoyancy when asset prices fall, as happened during the recent crisis. This can squeeze government budgets, even if during an economic downturn interest rates are low. The deterioration in the budget may also undermine perceptions of sustainability. 


\subsection{Financial sector weakness}

In principle, financial intermediation can help damp output volatility, especially when idiosyncratic shocks hit. However, when macroeconomic shocks are large or highly correlated, capital constraints place a limit on the liquidity services financial intermediaries can provide. In this context, highly leveraged banks will be less able to damp shocks (Yang and Tsatsaronis, 2012). Balance sheet vulnerabilities in the financial sector can be created by macroeconomic distortions, such as fiscal profligacy or exchange rate misalignments, as well as poor micro and macro prudential regulation, connected lending and governments interfering in the credit allocation process and the issuing of guarantees which encourage lending. As banks have moved away from funding through bank deposits (Schularick and Taylor, 2012), the greater role for securities markets has created a new set of vulnerabilities as they have been prone to abrupt changes in liquidity and corresponding difficulties of valuing assets. Also counter-party risks have been prominent during the economic crisis. When they materialise, they can cause spill-over and contagion effects because falling asset prices lead to losses that depress financial institutions' equity. As a consequence, they are forced to fire-sell assets, which, in turn further depresses asset prices and increases losses.

\section{Interactions across sectors and countries}

\subsection{Interactions across sectors}

At high levels of debt, balance sheet problems can migrate and cascade across sectors. Ultimately, as seen in the recent crisis, the government can be placed in an unenviable position of having to rescue the financial and even parts of the non-financial corporate sector. More indirectly, but quantitatively more important, government budgets are affected by cyclical weakness as other sectors deleverage, through automatic budget reactions as well as counter-cyclical fiscal policy. The simple Granger causality tests in Sutherland et al. (2012) suggest that run-ups in corporate borrowing in the previous five years (in both the financial and to a lesser extent the non-financial sector) tends to Granger cause increases in public sector debt. Recent experience graphically demonstrates that, at times, contagion from the private to the public sector can undermine government access to capital markets when "fiscal space" is limited, thereby forcing governments to become pro-cyclical during economic downturns.

Even in the absence of direct migration of balance sheet problems, concerns about the health of household, corporate or government balance sheets can affect the banking system, particularly when the banking sector has too little capital cushion. For example, fears about sovereign solvency can provoke runs on the banking system. Balance sheet vulnerabilities can also lead to self-fulfilling runs or sudden stops, when capital flows dry up (Mendoza et al., 2006). When corporate and household balance sheets are impaired, the subsequent deleveraging can affect other sectors. For example, corporate sector deleveraging will not only affect investment, but also employment and remuneration. This will have a direct effect on the household sector and an indirect effect on government revenues. In this light, when balance sheets are in poor health the effect of an adverse shock is likely to be felt more widely. Due to such repercussions, creditors can view private and public debt together when a crisis erupts (Diaz-Alejandro, 1984).

When several sectors are pursuing deleveraging simultaneously the consequences are likely to prolong and amplify the deleveraging process. If banks face difficulties in raising funds, because investors demand a higher return, for example, a process of deleveraging can occur that reduces the supply of credit. When households and the non-financial corporate sector are also highly leveraged the impact of bank deleveraging can be severe. This constellation will amplify and propagate large shocks. For example, in Japan, defaults on corporate loans and capital deterioration led banks to tighten credit conditions significantly. The ensuing substantial deleveraging of the non-financial corporate sector was largely due to a reduction in loans as a share of GDP, throughout the 1990s and into the 2000s. 


\subsection{International transmission and the exchange rate}

Over time, external assets and liabilities have grown, with debt accounting for a large share of liabilities (particularly in the United Kingdom). Why such large two-way debt flows exist is not well understood (Obstfeld, 2012). They can have positive effects on market functioning, but may also be related to tax shifting and regulatory arbitrage. An evaporation of liquidity and spike in counterparty risks because investors shift funds to safe havens can threaten financial stability, with consequent effects on activity.

The transmission of financial crises and exposure to foreign currency denominated debt can increase risk and amplify macroeconomic volatility (Korinek, 2010). Before the recent financial crisis financial market integration proceeded rapidly. During the crisis, retrenchment in the financial sector exposed many banks to maturity and currency mismatches, particularly for those banks reliant on cross-border wholesale financing (Tressel, 2010). But the crisis did not only affect those banks. Due to cross holdings, shocks to the financial sector can be transmitted quickly across countries. Ahrend and Goujard (2011) demonstrate how financial shocks transmit balance sheet vulnerabilities among banks in different countries through contagion effects. Cetorelli and Goldberg (2012), using data from US branches of foreign banks, show that the parent bank's exposure to asset-backed commercial paper had an impact on liquidity management. Banks most exposed were more likely to transfer money from the branches, with consequent declines in lending in the host country. Giannetti and Laeven (2012) find that in the syndicated loan market foreign banks export shocks in their home market to their host markets.

Empirical work suggests that financial openness exacerbates the effect of adverse financial shocks on real output (Aizenman et al., 2011). Such a pattern would be consistent with sudden stops à la Mendoza, though this finding is likely to be driven by non-OECD members in the panel. Fratzscher et al. (2011) find some evidence that unsustainable fiscal positions and the composition of government debt is correlated with currency crashes in advanced economies, while reserve currencies are shielded from this risk.

During the recent crisis concerns about debt overhangs arose in a number of countries, which had established a pegged exchange rate, such as Estonia, and had seen a significant build-up of private debt. In other countries, such as Hungary, households favoured mortgages in foreign currency exposing them to significant exchange rate risks.

Recent work by the OECD (Ahrend and Goujard, 2012) has found that structural policies affect the financial fragility associated with capital inflows. These policies include regulatory burdens on foreign direct investment, as well as stricter product market regulation, which have biased external liabilities away from FDI and towards bank debt. Similarly, tax systems that favour debt finance over equity finance have increased the share of external debt in corporate financing. In a similar way, housing policies that aim to prevent housing bubbles seem to diminish the bias towards external debt. Better banking supervision, including stringent information disclosure requirements and strict capital requirements, reduce the risk of financial crises and banking systems that were less leveraged and had lower credit to deposit ratios have been less affected by financial contagion.

\section{The secular rise in indebtedness and its impact on macroeconomic stability}

\subsection{Households can smooth consumption within limits}

While household debt has risen over time to historically high levels, household net financial wealth remains strongly positive (Figure 2). In a number of cases such as in the Netherlands and Denmark, the growth of household financial liabilities has been particularly pronounced and has reached very high levels. But in these countries, household financial assets are extremely high too - particularly pension funds and life insurance in the Netherlands - so that household net financial wealth remains significant. 
The fast growth of mortgage debt in many countries led to a divergence in the trends for household financial liabilities and assets. But rising house prices boosted the total asset side of household balance sheets, allowing households to take on more borrowing. Thus, while aggregate household financial liabilities were increasing, household financial and especially non-financial assets were also rising.

Figure 2. Household debt and net financial worth

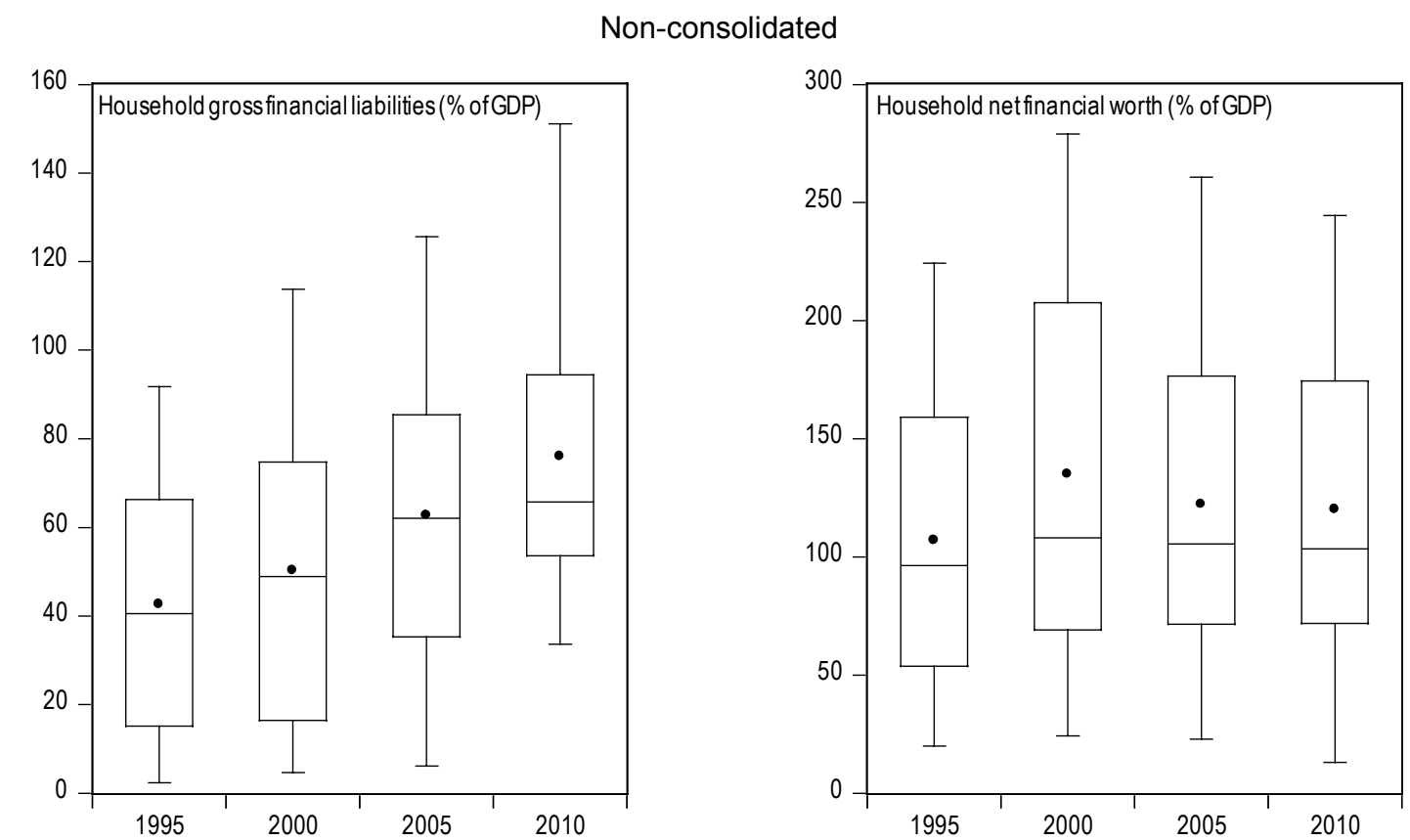

Note: These plots display the box that covers the observations between the $1^{\text {st }}$ and $3^{\text {rd }}$ quartiles, as well as the median (the horizontal bar) and the mean (the point). The whiskers extending from the box give the range that captures the observations which lie within 1.5 times the inter-quartile range from the $1^{\text {st }}$ and $3^{\text {rd }}$ quartiles.

Source: OECD National Accounts.

Borrowing is particularly relevant for housing and other durable goods' purchases. For these purchases, the services these goods confer are consumed over sometimes very long periods and as such borrowing allows consumption to be smoothed. Consumption smoothing cannot, however, explain the rise of debt/income ratios. A number of factors have contributed to the secular increase in household borrowing. These include financial market liberalisation and financial innovations - often connected with the housing market - creating a wider range of investment opportunities. In many countries financial market developments allowed borrowers to borrow more as well as affording broader access to credit markets. Earlier work by the Economics Department identified innovations in credit markets that eased access for lower-income borrowers and reduced financial constraints on first-time home-buyers (Girouard et al., 2006).

The macroeconomic environment and other factors can also play a role in influencing borrowing. Interest rates affect consumption through modifying prices inter-temporally whereas changes in expected income can also alter the desired level of consumption and borrowing. Furthermore, less uncertainty can contribute to lowering precautionary saving and prompt households to take on more debt. In some countries, demographic changes may account for some changes in household debt. For example, due to life cycle considerations a growing young population will likely raise debt as it aims at smoothing consumption over the lifetime. 
There is some evidence that following financial market liberalisation, household consumption became more sensitive to wealth and less to long-term income (Barrell and Davis, 2007) and thus more affected by volatile asset prices. A related factor has been increases in asset prices. In particular, house price appreciation allowed house owners to accumulate more debt (Dynan and Kohn, 2007), while also loan-to-value ratios increased in many countries. Deregulation in the mortgage market and financial innovation have been linked to household credit booms (Campbell and Hercowitz, 2005), leaving many households highly leveraged, sowing the seeds for a bust.

In the case of the United Kingdom, Armstrong (2012) presents evidence that mortgage borrowing was increasingly directed towards the bottom of the income distribution (see also Lucchino and Morelli, 2012) and that around the start of the recent financial crisis a large share of households were reporting being in a poor financial state. The distribution of borrowing could have an effect on consumption, if marginal propensities to consume between debtors and creditors differ (King, 1994). Creditors could react differently to interest rate changes than lenders, which may be related inter alia to differences in consumption baskets (for example, a change in interest rates leads to inter-temporal substitution and can change the opportunity cost of buying durable goods and housing). In this context, differences between borrowers and lenders, which may be related to differences in debt levels and leverage across the income distribution, may amplify macroeconomic disturbances when interest rates go up.

An area where policy could affect household borrowing, asset price and consumption volatility is through taxation. Taxation can influence housing demand, house prices and household leverage. Owner-occupied housing has often favourable tax treatment relative to other forms of capital investment. Imputed rental income on principal homes is not subject to income tax, except in a few countries. Even though most countries levy property taxes, these tend to be an imperfect substitute and are low in many countries. At the same time, mortgage interest payments can be deducted from the personal income tax base in about half of the OECD countries and a few countries provide tax credits for owner occupancy. The tax-favouring of housing tends to encourage excessive leverage and is capitalised into house prices (Capozza et al., 1996; Harris, 2010). Estimates by Andrews et al. (2011) suggest that in countries having more generous housing tax relief on debt financing costs, a positive demand shock translates into an increase in house prices that is around 50\% larger than in the typical OECD country. Andrews et al. (2011) also provide some evidence that mortgage interest deductibility correlates with increased real house price volatility, possibly reflecting the tendency for such policies to encourage leverage, by raising the after-tax return from engaging in speculative housing investments.

\subsection{Corporate sector leverage may affect investment volatility}

In contrast to household debt developments, the financial liabilities of the non-financial corporate sector have shown considerably more variation, with liabilities as a share of GDP rising and falling over time, notwithstanding the overall rise in average non-financial corporate sector debt (Figure 3). In general, until the financial crisis, leverage had been declining in the non-financial corporate sector.

Firms hold debt for a number of reasons (Myers, 2001). First, the trade-off theory suggests that firms weigh the costs and benefits of additional debt. The benefits include, for instance, tax advantages, while the cost of debt includes potential bankruptcy costs. In this context, firms target an optimal level of debt. Second, the pecking order theory suggests that equity issuance and to a lesser degree debt comes with a cost, arising from asymmetric information between managers and investors. Managers will prefer internal financing, before resorting to debt and ultimately equity. Managers would, thus, not target an optimal level of debt, but may need more debt financing when cash flow dries up. Third, the choice of corporate balance sheet structure depends on agency problems, arising from conflicts between managers, shareholders and bondholders. Shareholders may prefer more debt to align manager's incentives to maintain firm efficiency rather than invest in low quality projects when cash flow is ample. The empirical literature has given partial 
support to different theories of how corporations adjust balance sheets. Some evidence supports the pecking order theory for large firms, whereas the trade-off theory may be more relevant for small firms (Rajan and Zingales, 1995).

Figure 3. Non-financial corporate debt and leverage

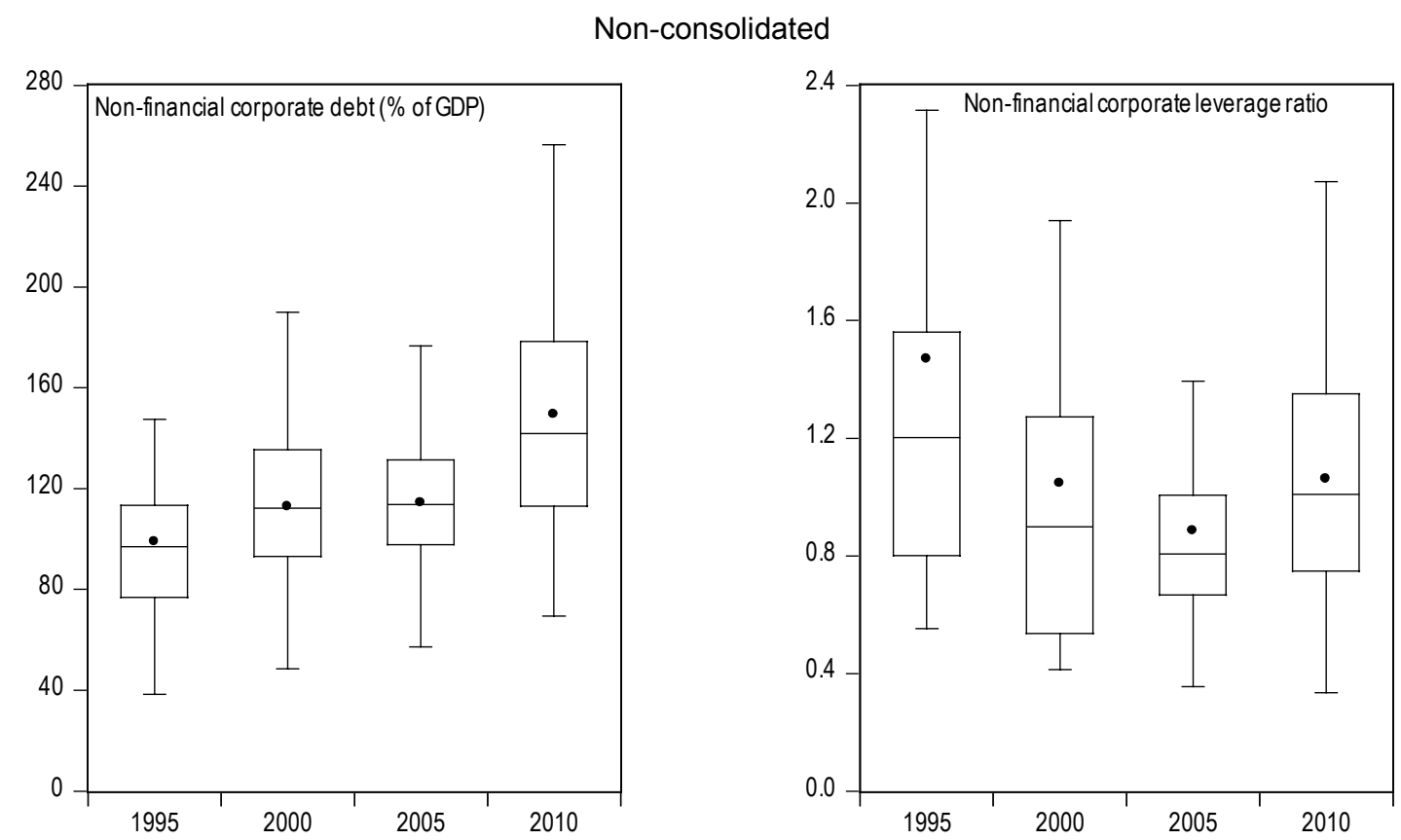

Note: These plots display the box that covers the observations between the $1^{\text {st }}$ and $3^{\text {rd }}$ quartiles, as well as the median (the horizontal bar) and the mean (the point). The whiskers extending from the box give the range that captures the observations which lie within 1.5 times the inter-quartile range from the $1^{\text {st }}$ and $3^{\text {rd }}$ quartiles.

Non-financial corporate debt is defined as financial liabilities other than equity and derivatives. The leverage ratio for the non-financial corporate sector is defined as financial liabilities other than equity and derivatives relative to equity.

Source: OECD National Accounts.

Much like households taking on debt to smooth consumption, borrowing by firms may help smooth investment, while high leverage may leave a firm exposed to shocks, such as changes in credit market conditions. This can have implications for macroeconomic stability since firms frequently use short-term debt counter-cyclically (Larrain, 2006). The state of non-financial corporate balance sheets, particularly leverage, matters for borrowing in normal times and especially during recessions (Jimenéz et al., 2012). When credit dries up this can have a marked effect on firms' ability to smooth activity (Gaiotti, 2011).

There are other features by which high debt levels can affect macroeconomic volatility. For instance, Davis and Stone (2004) found that investment falls more after the onset of a financial crisis when the debt-to-equity ratio is high. Econometric evidence also suggests that when short-term borrowing is large relative to share capital subsequent real investment volatility is more pronounced. This is consistent with evidence for some EU countries that greater reliance on bank financing is associated with higher investment volatility, while equity financing reduces volatility (Mullineux et al., 2011).

Aggregate data may mask important characteristics, such as how highly leveraged particular firms are and the quality of their collateral, which affect shock transmission or absorption. Higher leverage can depress investment (as well as dividends), which reduces leverage over time and brings it back on a sustainable track (Bonito and Young, 2007). Deleveraging by firms may become more pronounced when asset prices fall, particularly following a bubble. The effect of asset price declines may be further 
aggravated by fire sales (Shleifer and Vishny, 2010). Finally, negative effects on investment have been more pronounced when asset prices were more volatile (Davis, 2010).

If firms are highly leveraged, there may be consequences for macroeconomic performance that go beyond a downturn in investment. Corporate debt ratios have tended to fall substantially either during or following recessions (Jermann and Quadrini, 2006) and empirical evidence suggests that non-financial corporate deleveraging depresses employment, compensation as well as investment, while firms increase savings and cash holdings (Ruscher and Wolff, 2012).

In most tax systems, interest expenses are deductible from corporate income, but equity pay-outs are not, inducing firms to have higher leverage ratios. The choice of the capital structure involves a trade-off between the benefits and costs of debt financing. Costs are related, for instance, to financial distress, while the tax advantage contributes to the benefit of debt, with the benefit rising with the marginal tax rate. The wedge between the cost of internal and external financing pushes firms towards debt (Bernanke and Gertler, 1989; Bernanke et al., 1996, 1999; Carlstrom and Fuerst, 1997). The tax advantage can be substantial. Graham (2000), for example, estimated that the subsidy to debt financing is worth almost $10 \%$ of firm value in the United States. In a meta-analysis of 46 studies, Feld et al. (2011) find that the marginal tax effect on the leverage ratio is 0.3 . The tax effects are even higher for multinational firms, reflecting additional advantages from cross-border profit shifting opportunities and intra-company debt provides another device to respond to cross-country tax differences.

\subsection{The financial sector can be destabilising}

As the financial sector is largely the counterpart of the other institutional sectors' borrowing, the asset side of the financial sector is an important indicator of debt. Following financial market liberalisation, gross financial assets have grown, often substantially (Figure 4). Considerable heterogeneity in asset levels exists across countries. In particular, Luxembourg with its financial centre is an outlier, though non-consolidated debt levels are also very high in Ireland and the United Kingdom.

For the financial sector as a whole, leverage (defined as total assets as a ratio of share capital) has trended down in most OECD countries since the 1980s (Figure 4). When asset prices are rising, the value of both the numerator and denominator of the leverage ratio (assets/equity) rises. As the rise in the denominator is proportionally larger, the leverage ratio, other things being equal, will fall. However, a rise in equity underpins additional lending. Thus while the leverage ratio has generally been relatively stable or has even fallen, as in the case of the United States, financial sector assets as a share of GDP have nonetheless risen, often rapidly, such as in the United Kingdom. The peculiar pattern for Japan, where asset growth flattened out, predominately reflects developments in financial sector equity. Aggregate balance sheet numbers mask considerable heterogeneity within the sector. Banks and other financial intermediaries, which can be highly leveraged, are aggregated with firms such as mutual funds, pension funds and insurance companies that employ very little leverage (Palumbo and Parker, 2009).

Before the financial and economic crisis, growth in financial services' balance sheets was very fast. Furthermore, recessions that are preceded by large credit booms tend to be deeper and more protracted (Jordà et al., 2011). Banking sector pro-cyclicality can amplify cycles in the real economy and financial market instability can lead to severe downturns. While during normal times borrowing appears unaffected by the quality of bank balance sheets, this does appear to matter in recessions (Jimenéz et al., 2012). 
Figure 4. Leverage and balance sheet size in the financial sector Non-consolidated
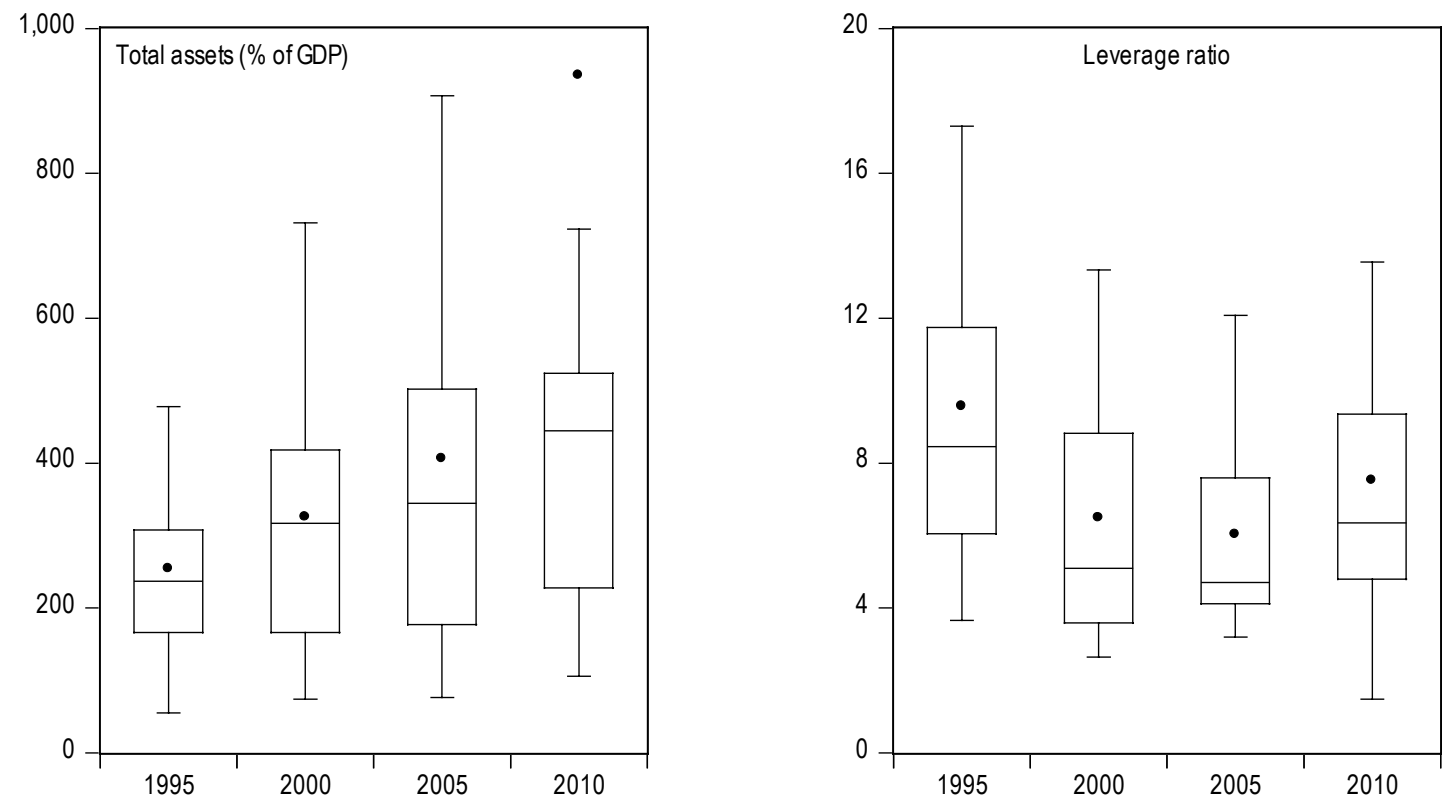

Note: These plots display the box that covers the observations between the $1^{\text {st }}$ and $3^{\text {rd }}$ quartiles, as well as the median (the horizontal bar) and the mean (the point). The whiskers extending from the box give the range that captures the observations which lie within 1.5 times the inter-quartile range from the $1^{\text {st }}$ and $3^{\text {rd }}$ quartiles. Financial sector leverage is defined as financial assets over equity. Outliers are excluded from the figures, which helps explain why the average for total assets is significantly above the median.

Source: OECD, National Accounts, ADB.

Bank-level data suggest that the banking system has become more pro-cyclical over time (Égert, 2010). Typically the leverage ratio for investment banks and large commercial banks is pro-cyclical, whereas for other banks it is a-cyclical, which is consistent with those banks having a target leverage ratio. Large banks typically have higher leverage ratios. The ratio of bank assets to GDP has moved ever more closely with the cycle since the late 1970s and banks have become increasingly leveraged. This has been accompanied by a rising number of banking crises. Furthermore, their funding structure has shifted away from deposits in many countries. Kaleml-Ozcan et al. (2011) argue that signs of emerging problems with large run-ups in leverage prior to the crisis were masked at the aggregate level. However, bank-level data reveal that investment banks and broker-dealers rapidly increased their balance sheets during the boom before 2007, particularly in the United States and to a somewhat lesser extent in Europe. Large banks also took larger risks, but mainly once the crisis had already erupted. Adrian and Shin (2010) proposed defining leverage as the speed at which the balance sheet grows. They found that when monetary policy was too loose (tight) financial institutions expand (contract) their balance sheets through collateralised borrowing (reducing the stock of repos/reverse repos). This tends to make bank lending pro-cyclical.

Pro-cyclical behaviour in credit supply can arise for a number of reasons: first, bank capital requirements, which are linked to the perceived riskiness of the assets, can induce pro-cyclicality if banks find it easier to adjust lending than capital to changing assessments of the riskiness of assets. Second, provisioning for bad loans can be pro-cyclical and, indeed, it often increases sharply during downturns. By depressing profits, it can have an impact on banks' ability to lend. Other developments have reinforced the pro-cyclicality of bank balance sheets. For example, banks that hold many illiquid assets or are reliant on short-term funding may be prone to pronounced pro-cyclicality in lending, due to changes in liquidity over the cycle. In addition, risk assessment that can be unduly pro-cyclical and remuneration policies can encourage excessive risk taking. 
When financial intermediaries have to adjust leverage it is often by reducing lending, rather than raising additional equity. Empirical evidence suggests that deleveraging occurs through credit tightening, particularly during a financial crisis (Jorda et al., 2011). Furthermore, the reaction of the financial sector to macroeconomic shocks can be relatively quick (Keen and de Mooij, 2012). Financial sector deleveraging can become pernicious, particularly when liquidity evaporates and banks are highly leveraged. For example, banks that face rising haircuts and margin calls when asset prices fall, may liquidate assets to improve their leverage ratios, putting further downward pressure on asset prices. The effect of these fire sales may reduce the recovery rates from defaulted loans, exacerbating losses. Furthermore, fire sales lead to negative wealth effects, a reduction of collateral value (Kiyotaki and Moore, 2008) and affect bank balance sheets, which undermines the ability of financial institutions to lend. Declining asset prices tend to curtail bank lending, but not corporate bond issuance. In a deteriorating macroeconomic environment banks may then have to make greater provisions for losses further denting credit supply. The cumulative effect of these shocks can have an important impact on the real economy. For example, Jermann and Quadrini (2012) show that financial shocks, or changes in credit conditions, are important determinants of output, investment and employment developments at the firm level.

Banks and other financial corporations benefit from tax incentives that promote the holding of debt, rather than equity. In this context, the situation is different from non-financial corporations, as regulatory requirements also influence financing decisions (debt is held for tax and equity for regulatory purposes). However, hybrid instruments complicate the analysis. In this area, there is little empirical work available. One study (Keen and de Mooij, 2012) suggests that bank capital structures are as responsive to tax asymmetries as those of non-financial firms. However, capital-constrained banks are only sensitive to changes in capital requirements, while those with large buffers show a strong response to taxation but not to capital requirements. Moreover, hybrid capital is the preferred source of debt finance and such debt is issued up to the point at which regulation limits its use. New bank taxes will reduce some of the incentive to use debt, often being targeted at wholesale financing by being based on liabilities other than Tier-1 and insured deposits (Hagemann, 2012).

\subsection{Government debt and stabilisation policy}

Following the financial crisis, public sector gross financial liabilities have risen fast in most countries, while remaining low in only a handful of countries (Figure 5). Debt levels had fallen somewhat during the last expansion, but this represented a pause for many countries in a longer-term upward drift in debt levels. For most OECD countries, developments in net financial liabilities generally mirror gross financial liabilities, although there are some notable exceptions, such as Finland and Norway, where governments have built up sizeable financial asset positions.

Governments hold debt for a number of reasons. The first is to conduct counter-cyclical fiscal policy to reduce the welfare costs of large declines in output and employment during downturns. A somewhat related rationale arises from tax smoothing to avoid the deadweight losses from periodically raising tax rates in the absence of smoothing. These reasons would justify holding debt periodically, but cannot explain rising debt levels. Governments may also build up debt by investing in assets or undertaking other spending from which future generations will benefit. In other cases, governments have issued debt to provide assets for the private sector. There are also a number of political economy reasons that give rise to a deficit bias. For example, spending surging prior to elections, the existence of soft-budget constraints for spending ministries and sub-central governments and the strategic use of debt to constrain the policy options for political opponents taking office (similar to the agency argument for corporate debt) would all tend to lead to larger deficits and higher debt levels. 
Figure 5. Government gross and net financial liabilities
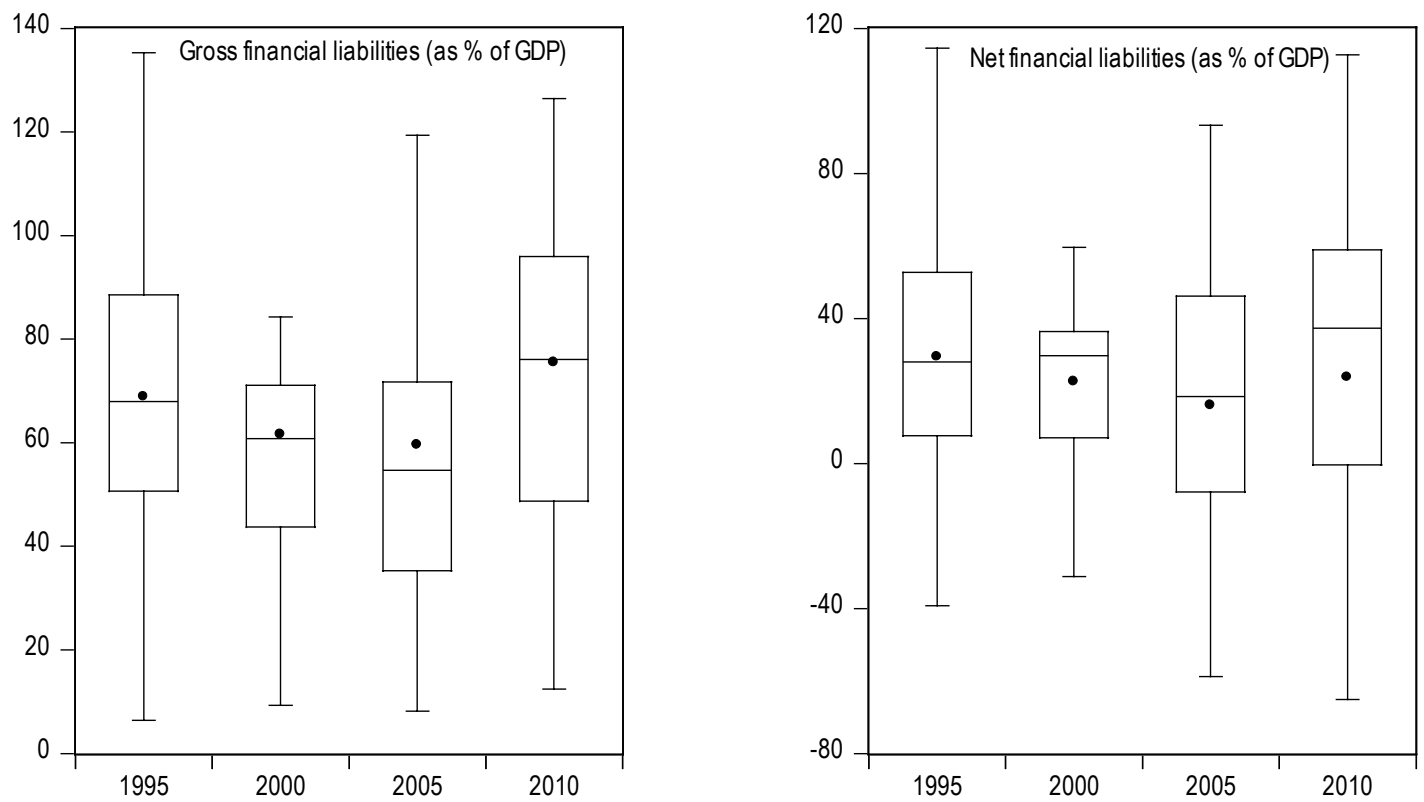

Note: These plots display the box that covers the observations between the $1^{\text {st }}$ and $3^{\text {rd }}$ quartiles, as well as the median (the horizontal bar) and the mean (the point). The whiskers extending from the box give the range that captures the observations which lie within 1.5 times the inter-quartile range from the $1^{\text {st }}$ and $3^{\text {rd }}$ quartiles.

Source: OECD National Accounts.

The effect of fiscal policy on macroeconomic stability is ambiguous. Increased government borrowing during a downturn cushions the effects of a large, adverse shock. In this context, increasing government debt is conducive to greater macroeconomic stability. However, there appear to be limits to the ability to stabilise the economy, potentially raising macroeconomic volatility.

A number of factors influence the effectiveness of fiscal policy in reducing macroeconomic volatility. Indeed, earlier OECD work on fiscal reaction functions found that fiscal policy becomes pro-cyclical at high levels of financial liabilities (Égert, 2010). The factors include:

- At high government levels, fiscal policy may become less effective due to Ricardian behaviour of households and firms. Recent empirical results (Röhn, 2010) suggest that the private saving offset becomes larger when debt is above $75 \%$ of GDP. ${ }^{3}$

- Government borrowing can lead to crowding out. Empirical estimates of the effect of government borrowing on interest rates suggests that there is a term premium, which is non-linear (Laubach, 2009; Égert, 2010; Turner and Spinelli, 2011), and which may be influenced by past fiscal performance (Haugh et al., 2009). In this context, government borrowing to stabilise aggregate demand may be counteracted by a higher cost of capital deterring investment. On the other hand, and particularly when balance sheets are impaired in other sectors and liquidity constraints bite, fiscal policy may have very large multipliers, which has implications for the size and duration of stimulus (de Long and Summers, 2012).

3. Sutherland (1997) develops a model showing that households may only become sufficiently worried about government debt levels when they imply that the needed stabilisation effort will directly affect them, rather than future generations, or will not be spread across a growing population. These findings reflect concern both about the current level of debt and the future sustainability of fiscal policy. 
- At very high debt levels, doubts about government solvency will arise (Corsetti et al., 2011). With fears of sovereign default raising interest rates for firms and households, crowding out effects can be exacerbated by news of weakening economic performance, as this makes fiscal consolidation targets harder to attain. Alternatively, the private sector may be affected through their balance sheet as government debt prices fall in reaction to increased fears of default.

- Fiscal rules, such as debt ceilings, could induce pro-cyclical fiscal policy when government debt levels are high. While this potential exists, the evidence that such fiscal rules present obstacles to macroeconomic stabilisation is less compelling (see for example, Gali and Perotti, 2003).

\section{The empirical relationship between debt and macroeconomic volatility}

The links discussed above suggest that high debt can lead to vulnerabilities and undermine macroeconomic stability. An adverse shock can tip the economy into recession. Examining the relationship between debt and macroeconomic stability faces a number of problems. First, the lack of long time series and comparable data presents a serious obstacle. For most countries, data only exist for the last business cycle, which was characterised by the "Great Moderation" and the "Great Recession". As such the analysis covers a period which is somewhat atypical. During this period debt rose in most countries, while macroeconomic volatility generally declined for a number of reasons, additional borrowing being one of them.

Second, accounting differences across countries complicate cross-country comparisons. For example, countries differ in reporting consolidated or non-consolidated balance sheets. In many cases, when countries report both consolidated and non-consolidated balance sheets, the differences in total economy financial liabilities are not large. However, in some cases, such as Italy, Denmark, France, Belgium, Greece and Hungary the differences can be substantial. The differences for the household sector between consolidated and non-consolidated financial liabilities are substantial for Estonia, Hungary, Poland and Slovakia. Gross and net debt can differ across countries and sectors depending on what items are included in debt. For example, whether all pension liabilities or just net underfunding is considered can vary with potentially considerable implications for sectoral financial liabilities. Another potential problem may arise if face value of debt masks differences due to debt structure, such as the division between principal and coupon payments (Dias et al., 2011).

Finally, aggregate sectoral balance sheet data may mask significant heterogeneity within a sector. For example, debt highly concentrated among households and firms that are least able to bear it may create vulnerabilities, even if the aggregate balance sheets appear reasonably healthy.

\subsection{Measures of macroeconomic stability and debt}

Following the approach of Blanchard and Simon (2001) the measures of macroeconomic stability or volatility are the 20 quarter rolling standard deviation of the real growth rate of GDP, consumption and investment. Two measures are calculated: the first using quarterly data (using only non-interpolated data) and the second using annual data, which helps increase the sample. The two measures are generally highly correlated (Figure 6). Large values for these volatility measures are typically associated with deep recessions, but there is a more varied picture at lower levels of volatility (Figure 7). The measures of debt are by institutional sector (non-financial corporate, financial, government and households) and then broken down by type of financial liability (shares, securities, loans, etc.). Summary statistics are presented in Table 1. 
Figure 6. Quarterly and annual measures of real volatility
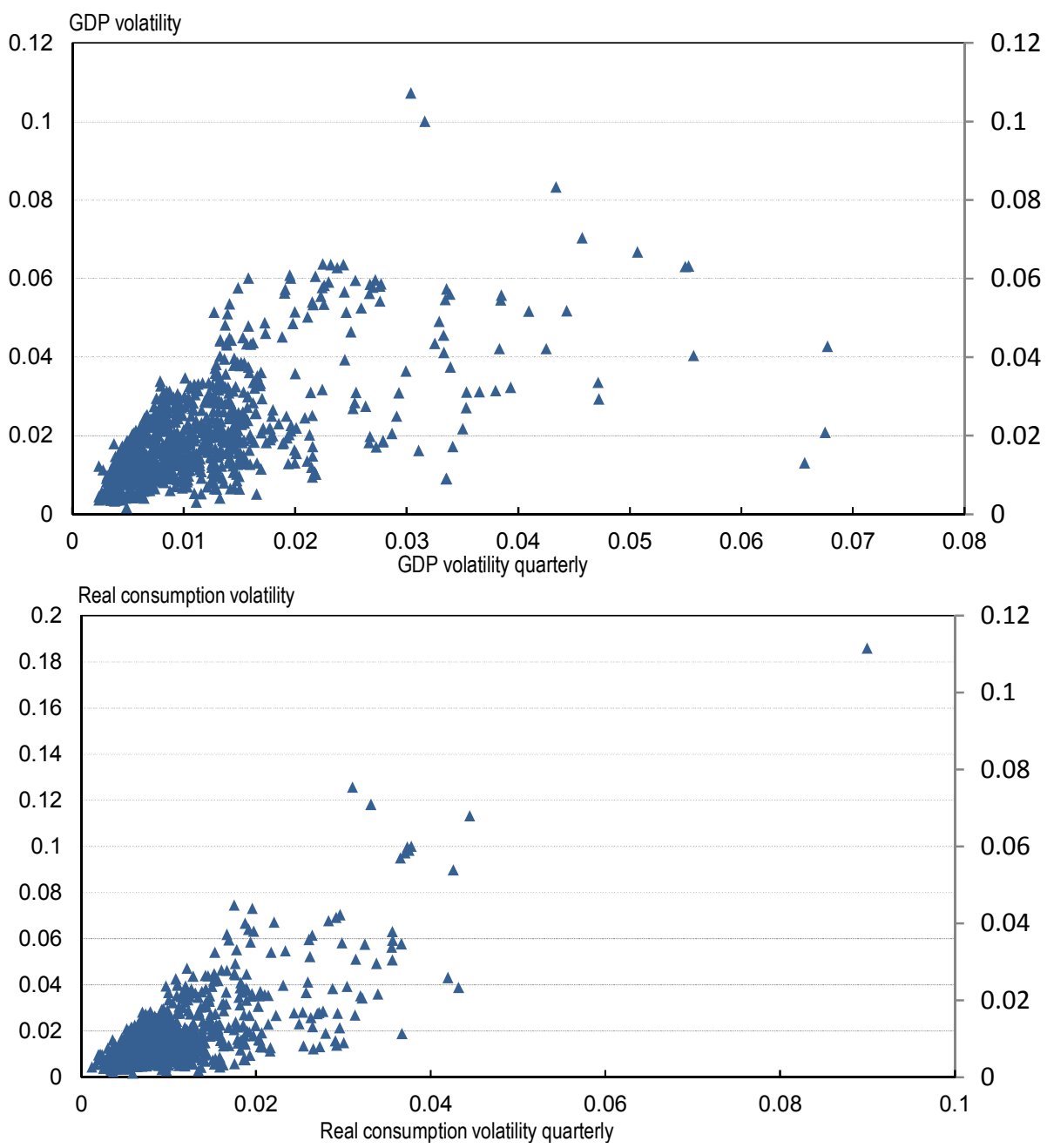

Figure 7. Real GDP volatility and the size of recessions

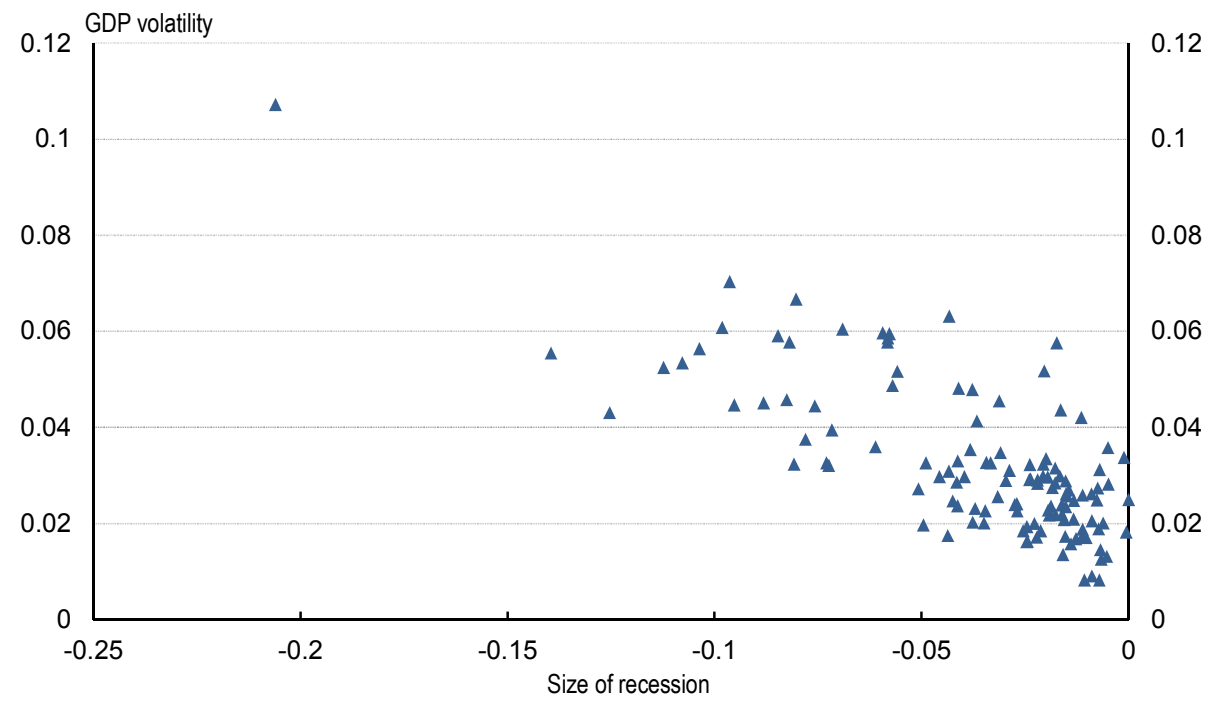


ECO/WKP(2012)83

Table 1. Summary statistics: volatility and debt

\begin{tabular}{|c|c|c|c|c|c|c|}
\hline & Mean & Median & Maximum & Minimum & $\begin{array}{l}\text { Standard } \\
\text { deviation }\end{array}$ & Observations \\
\hline GDP volatility annual & 0.022 & 0.019 & 0.098 & 0.006 & 0.012 & 287 \\
\hline GDP volatility quarterly & 0.012 & 0.010 & 0.056 & 0.003 & 0.008 & 211 \\
\hline Consumption volatility annual & 0.022 & 0.017 & 0.108 & 0.004 & 0.017 & 279 \\
\hline Consumption volatility quarterly & 0.011 & 0.009 & 0.043 & 0.003 & 0.007 & 199 \\
\hline Investment volatility annual & 0.068 & 0.056 & 0.330 & 0.011 & 0.043 & 286 \\
\hline Investment volatility quarterly & 0.036 & 0.027 & 0.221 & 0.008 & 0.025 & 199 \\
\hline \multicolumn{7}{|l|}{ Consolidated } \\
\hline \multicolumn{7}{|l|}{ Total liabilities (ratio to GDP) } \\
\hline Total economy & 6.760 & 4.115 & 123.718 & 0.694 & 16.915 & 96 \\
\hline Non-financial corporations & 1.857 & 1.695 & 5.732 & 0.304 & 0.815 & 96 \\
\hline Financial corporations & 4.826 & 2.176 & 117.218 & 0.533 & 16.152 & 96 \\
\hline Government & 0.645 & 0.606 & 1.503 & 0.088 & 0.294 & 96 \\
\hline Households & 0.544 & 0.515 & 1.507 & 0.048 & 0.313 & 96 \\
\hline \multicolumn{7}{|l|}{ Non-consolidated } \\
\hline \multicolumn{7}{|l|}{ Total liabilities (ratio to GDP) } \\
\hline Total economy & 9.797 & 7.156 & 138.357 & 1.506 & 16.917 & 123 \\
\hline Non-financial corporations & 2.561 & 2.418 & 11.069 & 0.304 & 1.379 & 123 \\
\hline Financial corporations & 5.870 & 3.266 & 127.350 & 0.692 & 15.742 & 124 \\
\hline Government & 0.739 & 0.677 & 2.161 & 0.099 & 0.367 & 129 \\
\hline Households & 0.599 & 0.574 & 1.511 & 0.048 & 0.319 & 128 \\
\hline
\end{tabular}

Note: The summary statistics are for a panel of non-overlapping five-year averages. Debt statistics are reported as a ratio of GDP.

The time-series properties of the data suggest that at annual frequency the series exhibit non-stationary characteristics. Panel unit root tests, reported in Table 2 are conducted for the full sample using annual data. For the samples using non-overlapping five-year period averages, the number of observations is typically small. The results suggest that most of the debt statistics are non-stationary. In some cases, the Levin, Lin and Chu statistics rejects the presence of a common unit root process in the level equation, but the Im, Pesaran and Shin test does not reject that all series have a unit root. The unit root tests suggest that the real GDP, investment and consumption volatility measures are a mixture of stationary and non-stationary processes. Consumption volatility appears to be trend stationary, whereas there is some evidence that GDP volatility and particularly real investment volatility has time-series properties that are characteristic of the presence of a unit root.

\subsection{Bivariate results}

Examining simple bivariate relationships between debt and volatility raises some econometric problems. When the series used in the baseline bivariate regressions (volatility measure and debt level) are of different orders of integration the regression is unbalanced. In this case, while the OLS estimate of the coefficient is consistent, the standard errors are biased and the critical values are nonstandard (Banerjee et al., 1993). If both variables are non-stationary there is also a potential problem of spurious correlation. In overlapping panels, Durbin-Watson statistics suggest that there are problems with serial correlation of the residuals. However, this is typically not a problem in the non-overlapping panels and these estimations are, therefore, the main results reported below. In order to avoid changes in the denominator influencing both the left and right hand side variables, debt variables are always included with a lag. Particularly in the non-overlapping panels the degrees of freedom are relatively limited. This arises due to the inclusion of both period and country fixed effects, and only recent debt data availability for most countries, with the data covering the unusual period of the great moderation followed by a severe crisis. 
Table 2. Times series properties of selected variables

\begin{tabular}{|c|c|c|c|c|c|c|c|c|c|c|c|c|}
\hline & \multicolumn{6}{|c|}{ Im, Pesaran and Shin test } & \multicolumn{6}{|c|}{ Levin, Lin and Chu test } \\
\hline & \multicolumn{3}{|c|}{ Constants, trends } & \multicolumn{3}{|c|}{$\begin{array}{l}\text { First difference, } \\
\text { constants }\end{array}$} & \multicolumn{3}{|c|}{ Constants, trends } & \multicolumn{3}{|c|}{ First difference, constants } \\
\hline & stat & p-val & obs & stat & p-val & obs & stat & p-val & obs & stat & p-val & obs \\
\hline GDP volatility & -2.20 & 0.01 & 1310 & -27.46 & 0.00 & 1276 & -0.52 & 0.30 & 1310 & -30.82 & 0.00 & 1276 \\
\hline GDP quarterly volatility & 1.66 & 0.95 & 923 & -15.67 & 0.00 & 890 & 0.37 & 0.64 & 923 & -20.75 & 0.00 & 890 \\
\hline Consumption volatility & -5.15 & 0.00 & 1269 & -28.06 & 0.00 & 1235 & -5.83 & 0.00 & 1269 & -33.37 & 0.00 & 1235 \\
\hline Consumption quarterly volatility & -2.74 & 0.00 & 848 & -17.03 & 0.00 & 815 & -15.27 & 0.00 & 850 & -23.60 & 0.00 & 815 \\
\hline Investment volatility & -1.24 & 0.11 & 1299 & -26.92 & 0.00 & 1265 & -0.92 & 0.18 & 1299 & -31.91 & 0.00 & 1265 \\
\hline Investment quarterly volatility & 1.12 & 0.87 & 843 & -14.91 & 0.00 & 810 & 22.69 & 1.00 & 845 & -19.65 & 0.00 & 810 \\
\hline \multicolumn{13}{|l|}{ Consolidated } \\
\hline \multicolumn{13}{|l|}{ Total liabilities } \\
\hline Total economy & 0.31 & 0.62 & 347 & -11.39 & 0.00 & 321 & -1.20 & 0.12 & 347 & -13.10 & 0.00 & 324 \\
\hline Financial corporations & 1.29 & 0.90 & 347 & -10.48 & 0.00 & 321 & -0.05 & 0.48 & 347 & -12.32 & 0.00 & 324 \\
\hline Non-financial corporations & -0.93 & 0.18 & 347 & -11.83 & 0.00 & 321 & -2.90 & 0.00 & 347 & -13.96 & 0.00 & 324 \\
\hline Government & 1.48 & 0.93 & 469 & -11.23 & 0.00 & 438 & -11.16 & 0.00 & 469 & -31.40 & 0.00 & 441 \\
\hline Households and NPISH & 0.73 & 0.77 & 362 & -7.48 & 0.00 & 336 & -3.06 & 0.00 & 362 & -8.47 & 0.00 & 339 \\
\hline \multicolumn{13}{|l|}{ Non-consolidated } \\
\hline \multicolumn{13}{|l|}{ Total liabilities } \\
\hline Total economy & 0.45 & 0.67 & 491 & -12.96 & 0.00 & 459 & -1.93 & 0.03 & 491 & -16.45 & 0.00 & 462 \\
\hline Financial corporations & 2.20 & 0.99 & 491 & -11.03 & 0.00 & 459 & 0.29 & 0.61 & 491 & -11.96 & 0.00 & 462 \\
\hline Non-financial corporations & -0.58 & 0.28 & 491 & -12.65 & 0.00 & 459 & -3.76 & 0.00 & 491 & -15.41 & 0.00 & 462 \\
\hline Government & 4.40 & 1.00 & 506 & -6.41 & 0.00 & 473 & 2.74 & 1.00 & 506 & -8.00 & 0.00 & 476 \\
\hline Households and NPISH & 1.56 & 0.94 & 507 & -7.09 & 0.00 & 475 & -2.15 & 0.02 & 507 & -7.54 & 0.00 & 478 \\
\hline
\end{tabular}

As a first examination of the data simple bivariate panel regressions are run. To account for significant cross-country heterogeneity and also the secular trends in the data the specification includes both country and period fixed effects. The explanatory variables are all lagged to minimise problems with spurious correlation, which may arise because changes in the denominator during recessions can simultaneously raise volatility and debt levels. In the baseline regressions, non-overlapping five year periods are used. First, this avoids econometric problems due to the averaging of the dependent variable. Second, five years typically do not represent a full business cycle and thus should be able to pick up greater volatility following a debt peak around a cyclical turning point. The approach is similar to Denizer et al. (2002), both in using non-overlapping multi-annual data and lagging the explanatory variables. As robustness tests, the estimations have been jackknifed, whereby each country is omitted from the sample sequentially, to examine the sensitivity of the results to individual countries as well as using the two measures of volatility (quarterly and annual) and also truncating the sample to exclude events after 2005 .

The simple regressions of different measures of levels and changes in different measures of debt as a share of GDP on real volatility suggest some links may exist, but they are relatively few and often not robust to changing the sample.

\subsubsection{GDP volatility}

Overall the links between sectoral debt levels and aggregate GDP volatility are weak and robustness testing suggests that the results are relatively unstable. The estimates reported in Table 3 show the coefficients for lagged levels and lagged changes in debt levels and the associated statistical significance. 
For most sectors the estimations do not reveal a consistent relationship for the different specifications examined in the robustness analysis. However, there is a somewhat more consistent relationship with government debt. Using government gross financial liabilities, as reported in the OECD Economic Outlook database, expands the sample (the results using balance sheet data are quantitatively similar as are results using net financial liabilities). Contemporaneous increases in debt have a stabilising effect. However, at higher levels of debt, if deficits push debt levels further up, subsequent volatility also appears to rise. This can be seen using two approaches. The first approach, based on simple bivariate regressions, suggests that changes in the level of debt are associated with lower subsequent volatility (although in the specification reported it is not statistically significant). However, subsequent volatility is larger at higher levels of debt. This is also clear from regressions with a shorter time span, excluding events after 2005 . The second approach is to model explicitly whether thresholds exist, which suggests that the interaction term becomes stronger at higher debt levels.

Table 3. GDP volatility and debt levels

Non-consolidated debt

\begin{tabular}{|c|c|c|c|c|c|c|c|}
\hline \multirow[b]{2}{*}{ Lagged variables } & \multicolumn{3}{|c|}{ Non-financial corporate liabilities } & \multicolumn{4}{|c|}{ Financial liabilities } \\
\hline & & & & & & & \\
\hline Level & 0.140 & & -0.246 & 0.031 & & -0.148 & \\
\hline First difference & & -0.027 & 0.091 & & -0.030 & -0.172 & \\
\hline Interaction & & & 0.034 & & & 0.028 & * \\
\hline Country fixed effects & Yes & Yes & Yes & Yes & Yes & Yes & \\
\hline Time fixed effects & Yes & Yes & Yes & Yes & Yes & Yes & \\
\hline \multirow[t]{2}{*}{ Observations } & 99 & 73 & 73 & 99 & 73 & 73 & \\
\hline & \multicolumn{3}{|c|}{ Government debt } & \multicolumn{4}{|c|}{ Household liabilities } \\
\hline \multicolumn{8}{|l|}{ Lagged variables } \\
\hline Level & 0.269 & * & 0.331 & 0.571 & & 0.381 & \\
\hline First difference & & -0.324 & -0.517 & & 0.735 & 1.977 & *** \\
\hline Interaction & & & 0.000 & & & -2.087 & *** \\
\hline Country fixed effects & Yes & Yes & Yes & Yes & Yes & Yes & \\
\hline Time fixed effects & Yes & Yes & Yes & Yes & Yes & Yes & \\
\hline Observations & 172 & 148 & 148 & 103 & 76 & 76 & \\
\hline
\end{tabular}

Note: Coefficients have been multiplied by 100 .

The threshold approach follows Égert (2010). In order to implement non-linear estimation, the sample is restricted to countries with longer time series. In this smaller group of countries, both the level and the first difference of gross government financial liabilities reduce subsequent volatility. As debt levels rise above 40 and $60 \%$ of GDP, however, the strength of the negative effect of high debt levels falls, suggesting that high levels of debt interfere with the ability of fiscal policy to stabilise the economy (Table 4).

Table 4. Non-linear relation between debt levels and output volatility

Dependent variable: Real GDP volatility quarterly

\begin{tabular}{|c|c|c|c|c|}
\hline Lagged variables & \multicolumn{2}{|c|}{ Coefficient } & \multicolumn{2}{|c|}{ Coefficient } \\
\hline First difference & -6.140 & $* * *$ & -7.000 & $\star \star *$ \\
\hline Interaction term & 0.057 & ** & 0.073 & *** \\
\hline Level & -0.002 & & & \\
\hline Level $<39 \%$ of GDP & & & -0.055 & *** \\
\hline Level between lower and upper thresholds & & & -0.025 & ** \\
\hline Level $>59 \%$ of GDP & & & -0.014 & * \\
\hline Adjusted R-squared & 0.08 & & 0.17 & \\
\hline Observations & 95 & & 95 & \\
\hline$P$ value for three regime model & & & 0 & \\
\hline
\end{tabular}




\subsubsection{Investment volatility}

Similar to GDP volatility, there is little consistent linkage between the aggregate sector debt levels, when expressed as a ratio of GDP and real investment volatility (Table 5). While total financial liabilities as a share of GDP of the non-financial corporate sector are not statistically significant, this is not the case when looking at measures of financial leverage. Higher levels of loans, particularly short-term loans, are associated with higher levels of real investment volatility (Table 6).

Table 5. Real investment volatility and debt levels

Non-consolidated debt as share of GDP

\begin{tabular}{|c|c|c|c|c|c|c|c|}
\hline \multirow[b]{2}{*}{ Lagged variables } & \multicolumn{3}{|c|}{ Non-financial corporate liabilities } & \multicolumn{4}{|c|}{ Financial sector liabilities } \\
\hline & 0.996 & & -0.254 & 0.283 & & -0.351 & \\
\hline Level & & 0.148 & 0.176 & & 0.024 & 0.019 & \\
\hline First difference & & & 0.048 & & & 1.419 & \\
\hline Interaction & 0.996 & & -0.254 & 0.283 & & -0.351 & \\
\hline Country fixed effects & Yes & Yes & Yes & Yes & Yes & Yes & \\
\hline Time fixed effects & Yes & Yes & Yes & Yes & Yes & Yes & \\
\hline \multirow[t]{2}{*}{ Observations } & 99 & 73 & 73 & 99 & 73 & 73 & \\
\hline & \multicolumn{3}{|c|}{ Government debt } & \multicolumn{4}{|c|}{ Household liabilities } \\
\hline Lagged variables & 0.001 & & 0.001 & 1.893 & & 0.059 & \\
\hline Level & & $-0.021 * *$ & -0.036 & & 0.676 & 2.929 & ** \\
\hline First difference & & & 0.000 & & & -0.845 & * \\
\hline Interaction & 0.001 & & 0.001 & 1.893 & & 0.059 & \\
\hline Country fixed effects & Yes & Yes & Yes & Yes & Yes & Yes & \\
\hline Time fixed effects & Yes & Yes & Yes & Yes & Yes & Yes & \\
\hline Observations & 168 & 145 & 145 & 130 & 76 & 76 & \\
\hline
\end{tabular}

Note: Coefficients have been multiplied by 100 .

Table 6. Real investment volatility and non-financial sector leverage

Non-consolidated debt

\begin{tabular}{|c|c|c|c|c|c|c|c|c|c|c|}
\hline Lagged variables & \multicolumn{5}{|c|}{ Total debt } & \multicolumn{5}{|c|}{ Short-term loans } \\
\hline Level & 0.413 & * & & 0.518 & & 5.951 & $* * *$ & & 3.516 & \\
\hline First difference & & & 0.014 & -1.294 & * & & & 0.167 & -7.634 & * \\
\hline Interaction & & & & 0.384 & * & & & & 26.969 & ** \\
\hline Country fixed effects & Yes & & Yes & Yes & & Yes & & Yes & Yes & \\
\hline Time fixed effects & Yes & & Yes & Yes & & Yes & & Yes & Yes & \\
\hline Observations & 102 & & 77 & 77 & & 78 & & 57 & 57 & \\
\hline
\end{tabular}

Note: coefficients have been multiplied by 100 .

\subsubsection{Consumption volatility}

The volatility of real consumption shows quite consistent links with household debt levels. For the coefficients reported in Table 7, both the level and the first difference are consistently statistically significant for the different measures of debt as well as household leverage. The estimation with the interaction term, however, is not significant. Additional results from jackknifing the sample (dropping one country at a time and re-estimation the equations) shows that this is driven by the inclusion of the Netherlands in the sample. When the Netherlands is dropped, the level coefficient is significant. Examining the sub-components of total household liabilities reveals that the aggregate link is largely driven by household loans (Table 8). 
ECO/WKP(2012)83

Table 7. Consumption volatility

Total household debt and leverage

\begin{tabular}{|c|c|c|c|c|c|c|c|c|c|}
\hline Lagged variables & \multicolumn{4}{|c|}{ Non-consolidated } & \multicolumn{5}{|c|}{ Consolidated } \\
\hline Level & 1.881 & *** & & 0.897 & 1.334 & ** & & & 0.811 \\
\hline First difference & & 1.38 & *** & 0.165 & & & 1.445 & * & 0.853 \\
\hline Interaction & & & & 0.691 & & & & & -0.149 \\
\hline Country fixed effects & Yes & Yes & & Yes & Yes & & Yes & & Yes \\
\hline Time fixed effects & Yes & Yes & & Yes & Yes & & Yes & & Yes \\
\hline Observations & 103 & 76 & & 76 & 75 & & 54 & & 54 \\
\hline
\end{tabular}

\begin{tabular}{lccc}
\hline & \multicolumn{3}{c}{ Leverage } \\
\cline { 2 - 4 } Lagged variables & \multicolumn{3}{c}{} \\
Level & 0.762 & $* * *$ & \\
First difference & & $0.889 \quad * * *$ & 0.416 \\
Interaction & & & 0.339 \\
\hline Country fixed effects & Yes & Yes & Yes \\
Time fixed effects & Yes & Yes & Yes \\
Observations & 102 & 75 & 75 \\
\hline
\end{tabular}

Note: Coefficients have been multiplied by 100 .

Table 8. Consumption volatility and household loans

Household loans as share of GDP, non-consolidated

\begin{tabular}{|c|c|c|c|c|c|c|c|c|c|c|c|c|}
\hline Lagged variables & \multicolumn{6}{|c|}{ Share of GDP } & \multicolumn{6}{|c|}{ Leverage } \\
\hline Level & 1.861 & $* * *$ & & & 1.060 & * & 0.780 & $* * *$ & & & 0.522 & * \\
\hline First difference & & & 1.407 & $* * *$ & 0.477 & & & & 0.927 & $* * *$ & 0.501 & \\
\hline Interaction & & & & & 0.042 & & & & & & -0.061 & \\
\hline Country fixed effects & Yes & & Yes & & Yes & & Yes & & Yes & & Yes & \\
\hline Time fixed effects & Yes & & Yes & & Yes & & Yes & & Yes & & Yes & \\
\hline Observations & 102 & & 75 & & 75 & & 102 & & 75 & & 75 & \\
\hline
\end{tabular}

Note: Coefficients have been multiplied by 100 .

\section{Does high debt lead to recessions?}

Accumulating additional debt allows households, firms and government smooth consumption and investment. However, at high debt levels, a debt overhang can prolong and deepen recessions. Whether debt induces recessions rather than aggravating the course of a recession is the focus of this section. As highlighted above, holding high levels of debt will limit the ability to borrow to smooth economic cycles and may thus contribute to aggravating a slowdown in growth into a recession. Similarly, the effects of swings in asset prices on consumption and investment, which are amplified by high leverage and debt deflation dynamics, can trigger a recession.

In this section, the links between debt and recessions are considered. Defining debt levels is complicated as financial market liberalisation and innovation have allowed debt levels as a share of GDP to rise over time, while differences across countries often reflect features particular to a given country (such as the extent of pension funding or the prevalence of interest only mortgages). Ideally, high and low debt levels would be set by fundamentals, but there is often little consensus on what these are. Against this background, to account for the upward trend in debt levels, which were partly driven by greater debt- 
holding capacity and the idiosyncratic features of the financial sectors across different countries, high and low debt periods are defined as deviations from the trend. First debt levels are calculated in relation to potential GDP to avoid cyclical movements in the denominator driving debt-to-GDP ratios down (up) when output is above (below) trend. In order to eliminate longer-term secular trends in the debt-to-potential GDP ratios a HP filter using a (quarterly) lambda of 400000 was used to extract the longer-term "cyclical" component. Unavoidably, using this method encounters the end-point problem, which given the severity of the recent recession is an important consideration.

Recessions occur more frequently when debt levels are high (Table 9). The frequency of recessions during total economy high-debt periods is almost twice as high as during low-debt periods (45 against 25 recessions). The expansions before the high-debt recessions are typically longer and larger, but the recessions are on average more severe, when household and corporate sector debt is high. Indeed, for high private-sector debt cycles there is a potential trade-off between the length of the expansion and the severity of the subsequent recession, with the trade-off worsening during the recent cycle (Box 1). These findings are consistent with Jorda et al. (2011) who, considering much longer time spans, find that more severe recessions follow expansions with larger build-ups of leverage. This is especially the case for real investment cycles, for which the size of the downturn is particularly pronounced relative to low-debt recessions. On the other hand, when the level of government debt is above trend recessions tend to be less frequent and less severe, reflecting that, at the top of the business cycle, budgetary positions are often unduly flattering. For example, revenue buoyancy related to surging asset prices can help contain government debt levels from rising, but the situation can quickly reverse with the onset of a recession.

Table 9. Characteristics of real GDP when debt is high and low

Earliest available year to 2010

\begin{tabular}{|c|c|c|c|c|c|}
\hline & \multicolumn{5}{|c|}{ GDP } \\
\hline & \multirow[b]{2}{*}{$\begin{array}{l}\text { Number of } \\
\text { recessions }\end{array}$} & \multicolumn{2}{|c|}{ Contraction } & \multicolumn{2}{|c|}{ Previous expansion } \\
\hline & & $\begin{array}{c}\text { Average } \\
\text { size }\end{array}$ & $\begin{array}{l}\text { Average } \\
\text { length }\end{array}$ & $\begin{array}{c}\text { Average } \\
\text { size }\end{array}$ & $\begin{array}{l}\text { Average } \\
\text { length }\end{array}$ \\
\hline \multicolumn{6}{|c|}{ Total economy debt } \\
\hline High & 45 & -4 & 4 & 26 & 29 \\
\hline Low & 25 & -2 & 4 & 16 & 20 \\
\hline \multicolumn{6}{|c|}{ Household debt } \\
\hline High & 42 & -4 & 4 & 28 & 31 \\
\hline Low & 32 & -2 & 3 & 15 & 18 \\
\hline \multicolumn{6}{|c|}{ Government debt } \\
\hline High & 27 & -2 & 3 & 18 & 23 \\
\hline Low & 48 & -4 & 4 & 25 & 27 \\
\hline \multicolumn{6}{|c|}{ Financial sector debt } \\
\hline High & 41 & -5 & 4 & 27 & 30 \\
\hline Low & 33 & -2 & 4 & 16 & 19 \\
\hline \multicolumn{6}{|c|}{ Non-financial sector debt } \\
\hline High & 46 & -4 & 4 & 25 & 28 \\
\hline Low & 21 & -3 & 4 & 19 & 23 \\
\hline
\end{tabular}

Note: The cycle is the classical business cycle (the algorithm used is described in Box 1). The size is the cumulative percentage change in the level and the length is the number of quarters of the contraction or expansion phases.

Accumulating additional debt allows households, firms and government smooth consumption and investment. However, at high debt levels, a debt overhang can prolong and deepen recessions. As highlighted above, holding high levels of debt will limit the ability to borrow to smooth economic cycles and may thus contribute to aggravating a slowdown in growth into a recession. Similarly, the effects of swings in asset prices on consumption and investment, which are amplified by high leverage and debt deflation dynamics, can trigger a recession. In some cases, deleveraging can be particularly abrupt, especially when debt levels are high. Large run-ups in household debt appear to be followed by large contractions in economic activity, particularly when coupled with house price declines. Tang and Upper (2012) find that the build-up of private sector indebtedness tends to be substantial before financial crises. 
Furthermore, Glick and Lansing (2010) find that the countries experiencing the largest consumption drops following the onset of the financial and economic crisis were also the countries that had experienced the largest run-up in house prices and household leverage.

\section{Box 1. Debt and the classical business cycle}

Following Canova (2007), a simple algorithm is used to identify classical business cycles for the level of real GDP, consumption and investment. ${ }^{1}$ Having identified turning points, the characteristics of expansions and (technical) recessions are determined in terms of length, measured by the number of quarters, and size, measured by the cumulative percentage change of the level of real GDP, consumption and investment.

In addition to the length and size of expansions and contractions, the ratio of the length and size between expansions and contractions provides information about asymmetries of business cycles. The following demonstrates how even small changes in the sample can alter the relative properties of expansions and contractions. For the total sample, the asymmetries between expansions and contractions in both length and amplitude are more pronounced for output and consumption than investment. Investment cycles are more volatile with the asymmetry of length and amplitude considerably smaller (Table 10). In comparison with all cycles, when total economy debt levels are above trend, cycle expansions are longer and somewhat larger relative to contractions. That high-debt expansions of real GDP, consumption and investment were larger relative to contractions is more clear-cut, when omitting the last cycle from the sample.

In sum, there appears to be some association of business cycle characteristics with debt levels. When debt is higher the expansion was often prolonged relative to the contraction. However, when the last cycle is included the severity of recessions considerably offset the advantage of the preceding long expansion.

Table 10. Business cycle asymmetries

Length in quarters and size in cumulative percentage change during expansions relative to contractions

\begin{tabular}{|c|c|c|c|c|c|c|}
\hline & \multicolumn{2}{|c|}{ GDP } & \multicolumn{2}{|c|}{ Consumption } & \multicolumn{2}{|c|}{ Investment } \\
\hline & Length & Size & Length & Size & Length & Size \\
\hline End-year of analysis & \multicolumn{6}{|c|}{ Total economy debt, all cycles } \\
\hline 2010 & 5.9 & 7.1 & 6.0 & 7.3 & 2.3 & 2.3 \\
\hline 2005 & 5.7 & 9.0 & 5.7 & 7.8 & 2.3 & 2.6 \\
\hline End-year of analysis & \multicolumn{6}{|c|}{ Total economy debt, debt above trend } \\
\hline 2010 & 7.8 & 7.3 & 7.7 & 10.3 & 3.2 & 3.3 \\
\hline 2005 & 8.5 & 22.8 & 8.5 & 24.2 & 3.6 & 6.0 \\
\hline
\end{tabular}

Note: 2010 and 2005 describe the terminal date in the sample used to calculate the business cycle asymmetries.

1. The algorithm requires smoothing the series of interest (GDP, investment and consumption) using a five point Spencer curve to eliminate the impact of idiosyncratic and high frequency volatility. Second, a dating rule identifies peaks (troughs) if they are larger (smaller) than the observations for the preceding and following two quarters. Third a censoring rule ensures that the peaks and troughs alternate and that the duration of the cycles is meaningful (at least five quarters in length from peak to peak or trough to trough) and the amplitude of the movement from peak to trough or trough to peak is larger than $1 \%$.

In order to examine the impact of debt levels on recessions, a simple probit model is estimated. ${ }^{4}$ The aim is to consider whether high debt levels help explain the occurrence of past recessions. Ex-post examinations of forecasting performance have tended to highlight that simple indicators can perform well in predicting growth, but the best indicator changes over time (Banerjee and Macellino, 2006; Stock and Watson, 2001). However, in a number of studies, the yield curve appears to contain useful information in signalling future recessions (Estrella, Rodrigues and Schich, 2003; Rudebusch and Williams, 2009, Wheelock and Wohar, 2009).

The benchmark probit estimation examines the role of debt in a parsimonious specification using the yield curve augmented by debt variables as explanatory variables (Table 11), with samples up to 2007 and then to 2010 in order to reveal the consequences of the crisis on the ex-post predictive properties of the

4. Earlier work in the Economics Department has used probit models to analyse turns in housing prices (Rousová and van den Noord, 2011). 
variables. The available debt data restrict estimation to annual rather than quarterly data. The available data create an unbalanced panel. To check robustness, smaller panels, for which a greater time dimension is available, are also used for consolidated and non-consolidated data. Notwithstanding the parsimonious specification, the estimations show that the yield spread has the expected negative sign and that debt levels have some predictive power. High levels of private sector debt increase the likelihood of a recession occurring during the following year.

The marginal effects reported in Table 11 indicate the strength that a change in the explanatory variables has on the probability of a recession occurring, evaluated at the mean of the variables. The effect on the probability of recession is strongest for household debt. Furthermore, the probability of recessions rises rapidly when household debt moves further from trend, reflecting the non-linearity of the probit estimator (Figure 8). The marginal effect becomes larger, rising to over 3. As a result, while the predicted recession probability is around $10 \%$ when household debt is at trend it rises to over $40 \%$ once it rises above trend by $10 \%$ of GDP (Figure 9). While the effect is large, such an increase above trend is rare. The marginal effects for the other sectors and for total economy debt are less powerful, though rising non-financial corporate debt has a somewhat stronger effect than either rising total economy debt or financial sector debt. The effect of higher levels of government debt relative to trend is negative and reasonably strong, but when using different measures of debt, the effect is not significant.

Table 11. Recessions and indebtedness: Probit estimations

Dependent variable is whether a (technical) recession occurs in the following year

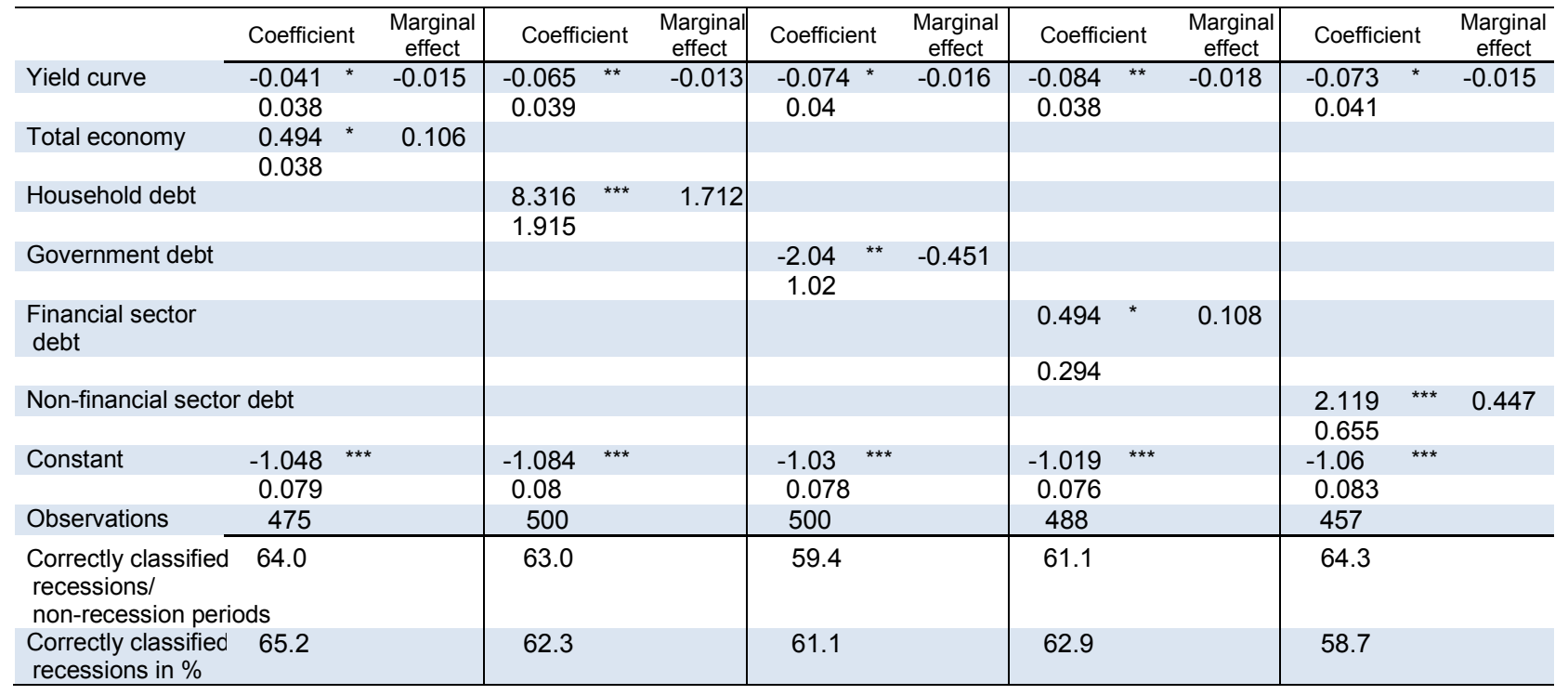

Note: Debt is measured as the "cyclical" component of debt relative to potential output. Robust standard errors are shown below the coefficient estimate with ${ }^{* *},{ }^{* *},{ }^{*}$ denoting significance at the 1, 5 and $10 \%$ significance levels, respectively. The marginal effect is the effect on the probability of a recession occurring due to a small change in the explanatory variable and evaluated at the means of the explanatory variables.

As robustness checks the simple probit models were re-estimated using a shorter sample, with longer lags and by jackknifing the sample. When using a shorter sample that excludes data after 2006, the coefficients for the yield curve are less statistically significant, but still with the expected negative sign (Table 12). For the most part, the findings for the debt levels are even more significant and the size of the marginal effect very similar to the full sample. The second robustness check examines the impact of using longer lags for the debt variables. Overall the explanatory power of the probit estimates declines, but the potential warning about the danger of a recession when household debt levels are high remains (Table 13). As a final test of robustness, the sample was also jackknifed to examine the impact of individual countries 
on the results. The results (not shown) reveal that the effects are somewhat stronger when Luxembourg is dropped from the sample. Otherwise, the coefficients are quite stable with respect to the composition of the sample.

Figure 8. The marginal effect of household debt relative to trend on the probability of a recession

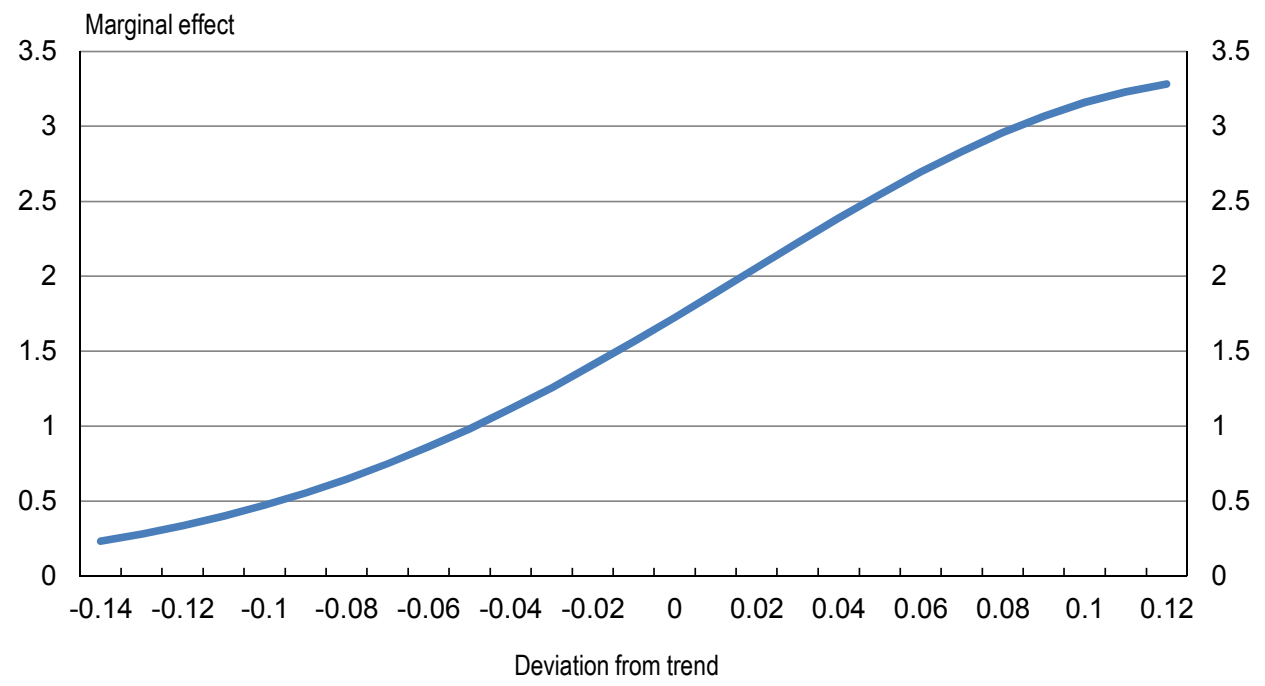

Note: Household debt is measured as the "cyclical" component of debt relative to potential output. The marginal effect is the effect on the probability of a recession occurring due to a small change in the explanatory variable evaluated at different points of the distribution of household debt.

Figure 9. The predicted probability of recession when household debt relative to trend rises

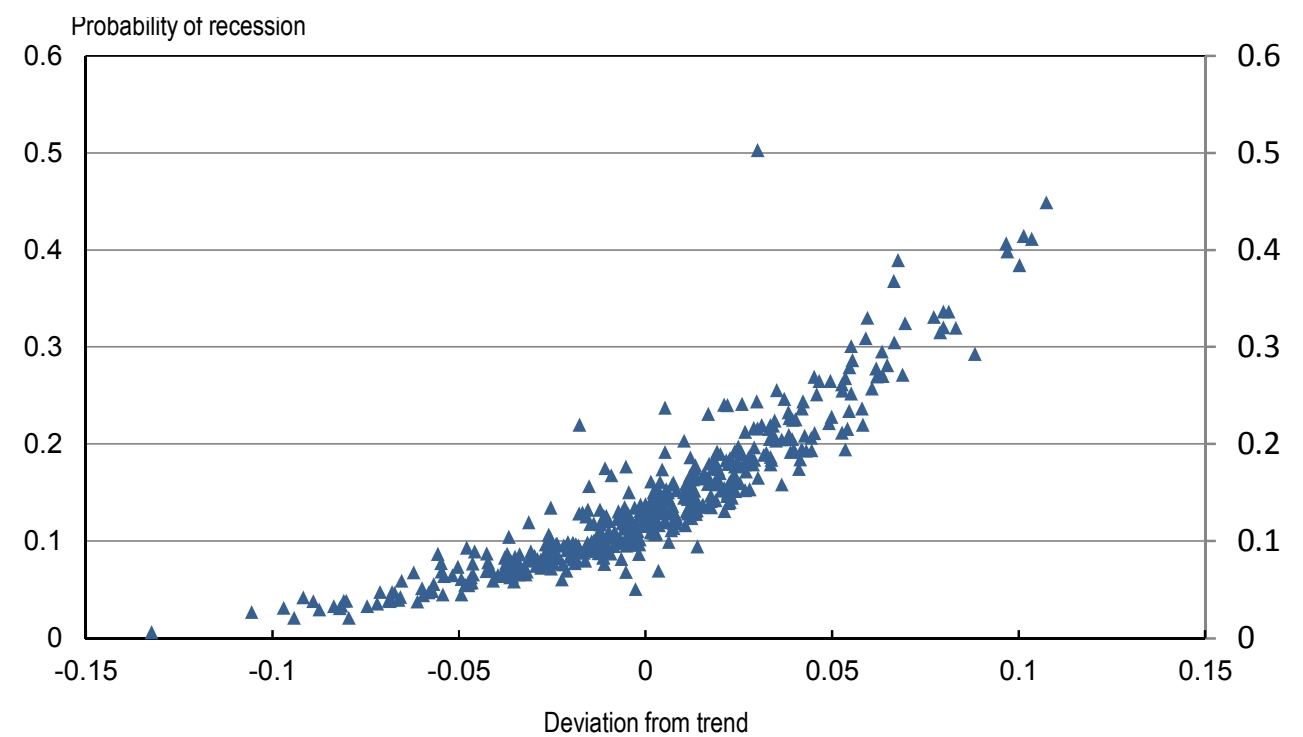

Note: Household debt is measured as the "cyclical" component of debt relative to potential output. The marginal effect is the effect on the probability of a recession occurring due to a small change in the explanatory variable evaluated at different points of the distribution of household debt. 
ECO/WKP(2012)83

Table 12. Recessions and indebtedness: Probit estimations using a shorter sample

Dependent variable is whether a (technical) recession occurs in the following year

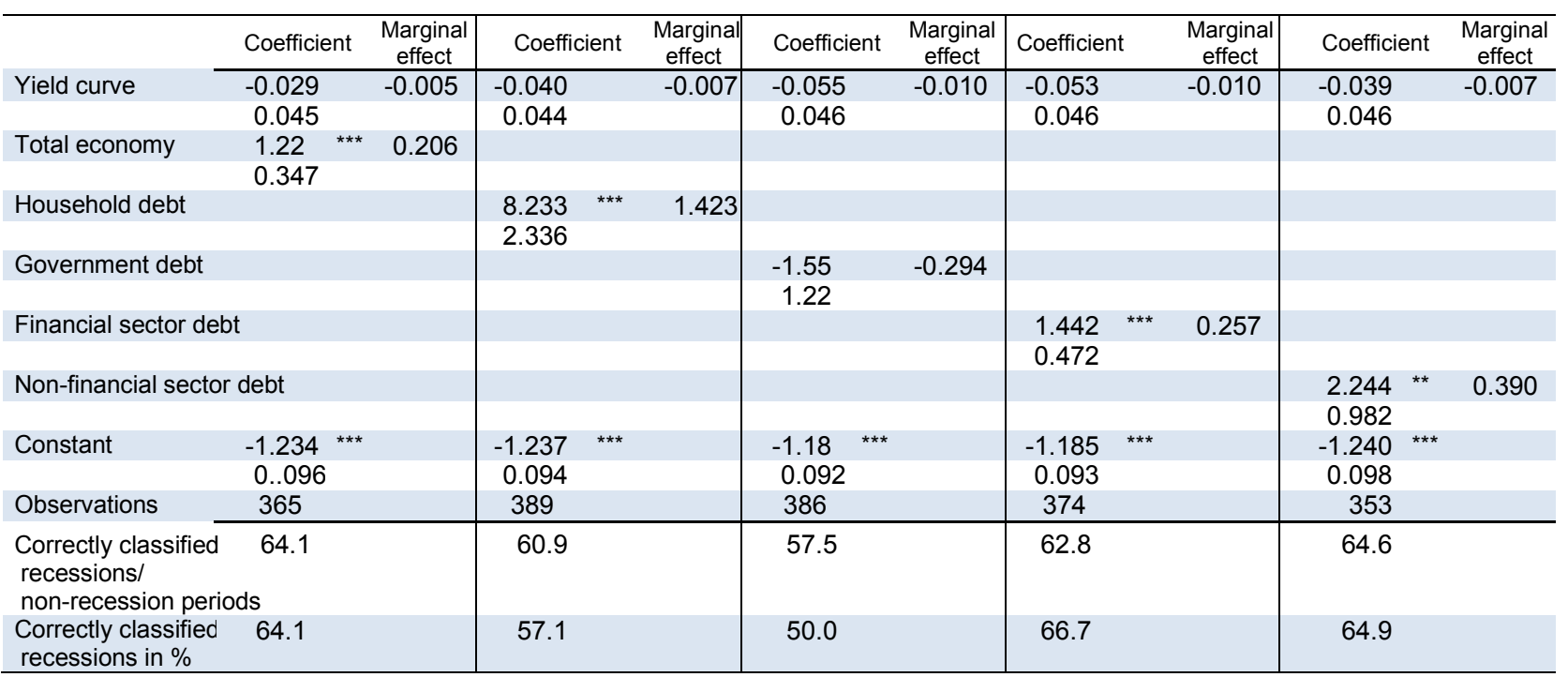

Note: Debt is measured as the "cyclical" component of debt relative to potential output. Robust standard errors are shown below the coefficient estimate with ${ }^{* * *},{ }^{* *},{ }^{*}$ denoting significance at the 1,5 and $10 \%$ significance levels, respectively. The marginal effect is the effect on the probability of a recession occurring due to a small change in the explanatory variable and evaluated at the means of the explanatory variables.

Table 13. Recessions and indebtedness: Probit estimations using a longer lag

Dependent variable is whether a (technical) recession occurs in the following year

\begin{tabular}{|c|c|c|c|c|c|c|c|c|c|c|c|c|}
\hline & Coefficient & $\begin{array}{c}\text { Marginal } \\
\text { effect }\end{array}$ & Coefficient & $\begin{array}{c}\text { Marginal } \\
\text { effect }\end{array}$ & Coefficient & $\begin{array}{c}\text { Marginal } \\
\text { effect }\end{array}$ & Coefficient & & $\begin{array}{c}\text { Marginal } \\
\text { effect }\end{array}$ & Coefficier & & $\begin{array}{c}\text { Marginal } \\
\text { effect }\end{array}$ \\
\hline Yield curve & $-0.081^{* \star}$ & -0.018 & -0.060 & -0.012 & $-0.090^{* *}$ & -0.020 & -0.092 & ** & -0.021 & -0.091 & ** & -0.020 \\
\hline & 0.039 & & 0.040 & & 0.040 & & 0.039 & & & 0.041 & & \\
\hline Total economy & 0.121 & 0.026 & & & & & & & & & & \\
\hline & 0223 & & & & & & & & & & & \\
\hline Household debt & & & $8.829^{* * *}$ & 1.839 & & & & & & & & \\
\hline & & & 1.976 & & & & & & & & & \\
\hline Government debt & & & & & -0.545 & -0.227 & & & & & & \\
\hline & & & & & 1.001 & & & & & & & \\
\hline $\begin{array}{l}\text { Financial sector } \\
\text { debt }\end{array}$ & & & & & & & 0.174 & * & 0.039 & & & \\
\hline & & & & & & & 0.251 & & & & & \\
\hline Non-financial sector & debt & & & & & & & & & -0.127 & & -0.028 \\
\hline & & & & & & & & & & 0.766 & & \\
\hline Constant & $-1.012^{* * *}$ & & $-1.087^{* * *}$ & & $-0.990^{* * *}$ & & -0.991 & $* * *$ & & -1.01 & $* * *$ & \\
\hline & 0.081 & & 0.083 & & 0.079 & & 0.078 & & & 0.083 & & \\
\hline Observations & 453 & & 477 & & 477 & & 465 & & & 437 & & \\
\hline $\begin{array}{l}\text { Correctly classified } \\
\text { recessions/ } \\
\text { non-recession perioc }\end{array}$ & $\begin{array}{l}66.0 \\
\text { ds }\end{array}$ & & 63.3 & & 66.3 & & 65.0 & & & 65.9 & & \\
\hline $\begin{array}{l}\text { Correctly classified } \\
\text { recessions in } \%\end{array}$ & 54.7 & & 58.2 & & 52.9 & & 50.0 & & & 50.8 & & \\
\hline
\end{tabular}

Note: Debt is measured as the "cyclical" component of debt relative to potential output. Robust standard errors are shown below the coefficient estimate with ${ }^{* * *},{ }^{* *},{ }^{*}$ denoting significance at the 1, 5 and $10 \%$ significance levels, respectively. The marginal effect is the effect on the probability of a recession occurring due to a small change in the explanatory variable and evaluated at the means of the explanatory variables. 


\section{Conclusions}

While debt performs important roles in smoothing economic activity and enhancing welfare, high debt levels create a number of vulnerabilities, which can also amplify and transmit shocks through the economy. The relationship between private sector debt levels and measures of macroeconomic volatility do not reveal strong, robust links with aggregate output. However, high government debt levels appear to be followed by higher output volatility. When examining the volatility of GDP components, high levels of household and non-financial corporate debt precede greater consumption and investment volatility, respectively. The empirical evidence reveals stronger links between debt and business cycle characteristics, including the probability of a recession occurring. High private sector debt levels relative to trend appear ex post to contribute to a higher probability of recessions occurring. Furthermore, the recessions when debt levels are high are deeper (though not necessary longer in the movement from the peak to the trough of the cycle) and typically follow prolonged expansions. Government debt typically rises above trend following the beginning of a downturn. There appears to be a migration of debt levels across balance sheets.

The recent economic and financial crisis has caused a loss of wealth that was unexpectedly large, a global recession and in its wake, a sovereign debt crisis in some European countries that threatens the monetary union. Many lessons have been learnt and policies are being deployed in many areas to prevent severe crisis from recurring. However, an important feature of crises is that they come as a surprise. While some economists pointed to the dangers of real estate bubbles, excessive leverage, lax monetary policy and weak financial market regulation, few linked the different pressures or saw the potential severity of the coming crisis. An important element of surprise was less the decline of overvalued housing prices, but rather the distress in many parts of the financial system, even those distant from the sub-prime market. Linkages across markets and countries have become increasingly complex and the next crisis could have different ingredients, which will again be very difficult to pinpoint ex ante (Caballero and Kurlat, 2009). It is, therefore, important to constrain run-ups in debt as well as taking out insurance to cope with future surprises by increasing the shock absorption capacity of financial systems and of governments. 


\section{REFERENCES}

Adrian, T. and H. Shin (2010), "Liquidity and Leverage", Journal of Financial Intermediation, Vol. 19, pp. 418-437.

Ahrend, R. and A. Goujard (2011), "Drivers of Systemic Banking Crisis: the Role of Bank-balance-sheet Contagion and Financial Account Structure", OECD Economic Department Working Papers, No. 902, OECD Publishing.

Ahrend, R. and A. Goujard (2012), "International Capital Mobility and Financial Fragility: Part 3. How Do Structural Policies Affect Financial Crisis? Evidence from Past Crises across OECD and Emerging Economies", OECD Economics Department Working Papers, No. 966, OECD Publishing.

Aiyar, S., C. Calomiris and T. Wieladek (2012), "Does Macropru Leak? Evidence from a UK Policy Experiment", Bank of England Working Paper, No. 445.

Aizenman, J., B. Pinto and V. Sushko (2011), "Financial Sector Ups and Downs and the Real Sector: Big Hindrance, Little Help", NBER Working Paper, No. 17530.

Allen, M., C. Rosenberg, C. Keller, B. Setser and N. Roubini (2002), “A Balance Sheet Approach to the Financial Crisis", IMF Working Paper, No. WP/02/210.

Andrews, A., A. Caldera Sánchez and Å. Johansson (2011), "Housing Markets and Structural Policies in OECD Countries", OECD Economics Department Working Papers, No. 836, OECD Publishing.

Armstrong, A. (2012), “UK Household Rebalancing”, National Institute Economic Review, No. 220.

Banerjee, A., J. Dolado, J. Galbraith and D. Hendry (1993), Co-Integration, Error-Correction, and the Econometric Analysis of Non-Stationary Data, Oxford University Press.

Banerjee, A. and M. Marcellino (2006), "Are there any Reliable Leading Indicators for US Inflation and Growth?", International Journal of Forecasting, Vol. 22, pp. 137-151.

Barrell, R. and E. Davis (2006), "Financial Liberalisation, Consumption and Wealth Effects in Seven OECD Countries", Scottish Journal of Political Economy, Vol. 54, pp. 254-267.

Barrell, R., E. Davis and O. Pomerantz (2006), "Costs of Financial Instability, Household-sector Balance Sheets and Consumption”, Journal of Financial Stability, Vol. 2, pp. 194-216.

Bernanke, B. and M. Gertler (1989), "Agency Costs, Net Worth and Business Fluctuations", American Economic Review, Vol. 79.

Bernanke, B. and M. Gertler (1990), "Financial Fragility and Economic Performance", Quarterly Journal of Economics, Vol. 105. 
Bernanke, B., M. Gertler and S. Gilchrist (1996), “The Financial Accelerator and the Flight to Quality”, The Review of Economics and Statistics, MIT Press, Vol. 78, No. 1, pp. 1-15, February.

Bernanke, B., M. Gertler and S. Gilchrist (1999), "The Financial Accelerator in a Quantitative Business Cycle Framework", in: J.B. Taylor and M. Woodford (eds.), Handbook of Macroeconomics, edition 1, Vol. 1, Chapter 21, pp. 1341-1393, Elsevier.

Bianchi, J. (2011), "Overborrowing and Systemic Externalities in the Business Cycle”, American Economic Review, Vol. 101, pp. 3400-3426.

Blanchard, O. and Simon (2001), "The Long and Large Decline in U.S. Output Volatility", Brookings Papers on Economic Activity, No. 1, pp. 135-64.

Bonito, A. and G. Young (2007), "Financial Pressure and Balance Sheet Adjustment by Firms", Oxford Bulletin of Economics and Statistics, Vol. 69, No. 5, pp. 581-602.

Campbell, J. and Z. Hercowitz (2005), "The Role of Collateralized Household Debt in Macroeconomic Stabilization", NBER Working Paper, No. 11330.

Canova, F. (2007), Methods for Applied Macroeconomic Research, Princeton University Press.

Capozza, D. et al. (1996), "Taxes, Mortgage Borrowing, and Residential Land Prices", in H.J. Aaron and W.G. Gale (eds.), Economic Effects of Federal Tax Reform, Brookings Institution Press, Washington, pp. 171-198.

Carlstrom, C. and T. Fuerst (1997), "Agency Costs, Net Worth, and Business Fluctuations: A Computable General Equilibrium Analysis", American Economic Review, Vol. 87.

Cetorelli, N. and L. Goldberg (2012), "Banking Globalization and Monetary Transmission", Journal of Finance, Vol. 67.

Corsetti, G., K. Kuester, A. Meier and G. Müller (2011), "Sovereign Risk and Macroeconomic Stability”, Mimeo.

Davis, E. (2010), “Asset Prices and Real Economic Activity”, OECD Economics Department Working Papers, No. 764, OECD Publishing.

Davis, E. and M. Stone (2004), “Corporate Financial Structure and Financial Stability”, Journal of Financial Stability, Vol 1.

DeLong, B. and L. Summers (2012), “Fiscal Policy in a Depressed Economy”, Mimeo.

Denizer, C., M. Iyigum and A. Owne (2002), "Finance and Macroeconomic Volatility", Contributions to Macroeconomics, Vol. 2.

Dias, D., C. Richmond and M. Wright (2011), "The Stock of External Sovereign Debt: Can We Take the Data at Face Value?", NBER Working Paper, No. 17551.

Diaz-Alejandro, C. (1985), “Good-bye Financial Repression, Hello Financial Crash”, Journal of Development Economics", Vol. 19, pp. 1-24. 
Dynan, K. and D. Kohn (2007), "The Rise of U.S. Household Indebtedness: Causes and Consequences", FEDS Working Paper, No. 2007-37.

Égert, B. (2010), "Fiscal Policy Reaction to the Cycle in the OECD: Pro- or Counter-cyclical?", OECD Economics Department Working Papers, No. 763, OECD Publishing.

Égert, B. (2012), "Public Debt, Economic Growth and Nonlinear Effects: Myth or Reality?", OECD Economics Department Working Papers, No. 993, OECD Publishing.

Égert, B. and D. Sutherland (2012), "The Nature of Financial and Real Business Cycles: The Great Moderation and Banking Sector Pro-cyclicality", OECD Economics Department Working Papers, No. 938, OECD Publishing.

Estrella, A., A. Rodrigues and S. Schich (2003), "How Stable Is the Predictive Power of the Yield Curve? Evidence from Germany and the United States", Review of Economics and Statistics, Vol. 85, No. 3, pp. 629-644.

Feld, L.P. et al. (2011), "Capital Structure Choice and Company Taxation: A Meta-Study", CESIFO Working Paper, No. 3400.

Fratzscher, M., A. Mehl and I. Vansteenkiste (2011), "130 Years of Fiscal Vulnerabilities and Currency Crashes in Advanced Countries”, IMF Economic Review, Vol. 59, No. 4, pp. 683-716.

Gaiotti, E. (2011), "Credit Availability and Investment in Italy: Lessons from the 'Great Recession"”, Banca d'Italia Working Paper, No. 793.

Gali, J. and R. Perotti (2003), "Fiscal Policy and Monetary Integration in Europe", Economic Policy, Vol. 18, pp. 533-572.

Giannetti, M., and L. Laeven (2012), "Flight Home, Flight Abroad, and International Credit Cycles", American Economic Review: Papers \& Proceedings, Vol. 102, No. 3, pp. 219-224.

Girouard, N., M. Kennedy and C. André (2006), "Has the Rise in Debt Made Households More Vulnerable?", OECD Economics Department Working Papers, No. 534, OECD Publishing.

Glick, R. and K. Lansing (2010), "Global Household Leverage, House Prices, and Consumption", Federal Reserve Bank of San Francisco, Economic Letter, No. 2010-01.

Hagemann, R. (2012), "Fiscal Consolidation: Part 6. What Are the Best Policy Instruments for Fiscal Consolidation?", OECD Economics Department Working Papers, No. 937, OECD Publishing.

Harris, B. (2010), “The Effect of Proposed Tax Reforms on Metropolitan Housing Prices", Tax Policy Center Working Paper, April.

Haugh, D., P. Ollivaud and D. Turner (2009), "What Drives Sovereign Risk Premiums? An Analysis of Recent Evidence from the Euro Area", OECD Economics Department Working Papers, No. 718, OECD Publishing.

Jermann, U. and V. Quadrini (2006), "Financial Innovation and Macroeconomic Volatility", NBER Working Paper, No. 12308. 
Jimenéz, G., S. Ongena, J-L. Peydró and J. Saurina (2012), “Credit Supply Versus Demand: Bank and Firm Balance-sheet Channels in Good and Crisis Times", Tilberg University, European Banking Center Discussion Paper, No. 2012-003.

Jorda, O., M. Schularick and A. Talyor (2011), "When Credit Bites Back: Leverage, Business Cycles, and Crises”, Federal Reserve Bank of San Francisco Working Paper, No. 2011-27.

Kalemli-Ozcan, S., B. Sorensen and S. Yesiltas (2011), "Leverage across Firms, Banks and Countries”, Mimeo.

Keen, M. and R. de Mooij (2012), “Debt, Taxes, and Banks”, IMF Working Paper, No. WP/12/48.

King, M. (1994), "Debt Deflation: Theory and Evidence", European Economic Review, Vol. 38, pp. 419-445.

Kiyotaki, N. and J. Moore (1997), “Credit Cycles”, Journal of Political Economy, Vol. 105.

Korinek, A. (2011), "Foreign Currency Debt, Risk Premia and Macroeconomic Volatility", European Economic Review, Vol. 55.

Larrain, B. (2006), “Do Banks Affect the Level and Composition of Industrial Volatility?”, Journal of Finance, Vol. LXI, No. 4, pp. 1897-1925.

Laubach, T. (2003), "New Evidence on the Interest Rate Effects of Budget Deficits and Debt", Journal of the European Economic Association, Vol. 7.

Lucchino, P. and S. Morelli (2012), "Inequality, Debt and Growth", Report for the Resolution Foundation.

Mendoza, E. and K. Smith (2006), "Quantitative Implications of a Debt-deflation Theory of Sudden Stops and Asset Prices", Journal of International Economics, Vol. 70, pp. 82-114.

Mullineux, A., V. Murinde and R. Sensarma (2011), "Corporate Financing and Macroeconomic Volatility in the European Union", International Economics and Economic Policy, Vol. 8.

Myers, S. (2001), “Capital Structure”, Journal of Economic Perspectives, Vol. 15, No. 2, pp. 81-102.

Obstfeld, M. (2012), "Does the Current Account Still Matter?", American Economic Review: Papers \& Proceedings, Vol. 102, No. 3, pp. 1-23.

OECD (2012), OECD Economic Outlook, Vol. 2012/1, OECD Publishing.

Palumbo, M. and J. Parker (2009), "The Integrated Financial and Real System of National Accounts for the United States: Does It Presage the Financial Crisis?", NBER Working Paper, No. 14663.

Rajan, R. and L. Zingales (1995), "What Do We Know about Capital Structure? Some Evidence from International Data", Journal of Finance, Vol. 50, pp. 1421-1460.

Röhn, O. (2010), "New Evidence on the Private Saving Offset and Ricardian Equivalence", OECD Economics Department Working Papers, No. 762, OECD Publishing.

Rousová, L. and P. van den Noord (2011), "Predicting Peaks and Troughs in Real House Prices", OECD Economics Department Working Papers, No. 882, OECD Publishing. 
Rudebusch, G. and J. Williams (2012), "Forecasting Recessions: The Puzzle of the Enduring Power of the Yield Curve", Journal of Business and Economic Statistics, Vol. 27, No. 4, pp. 492-503.

Ruscher, E., and G. Wolff (2012), "Corporate Balance Sheet Adjustment: Stylized Facts, Causes and Consequences”, European Economy Economic Papers, No. 449.

Schularick, M. and A. Taylor (2012), "Credit Booms Gone Bust: Monetary Policy, Leverage Cycles, and Financial Crises, 1870-2008”, American Economic Review, Vol. 102.

Shleifer, A. and R. Vishny (2010), "Fire Sales in Finance and Macroeconomics", NBER Working Paper, No. 16642.

Stock, J. and M. Watson (2001), "Forecasting Output and Inflation: The Role of Asset Prices", NBER Working Paper, No. 8180.

Sutherland, A. (1997), "Fiscal Crises and Aggregate Demand: Can High Public Debt Reverse the Effects of Fiscal Policy?", Journal of Public Economics, Vol. 65, pp. 147-162.

Sutherland, D., P. Hoeller, R. Merola and V. Ziemann (2012), "Debt and Macroeconomic Stability", OECD Economics Department Working Papers, No. 1003, OECD Publishing.

Tang, G. and C. Upper (2010), "Debt Reduction after Crises", BIS Quarterly Review, September.

Tessel, T. (2010), "Financial Contagion through Bank Deleveraging: Stylized Facts and Simulations Applied to the Financial Crisis", IMF Working Paper, No. WP/10/236.

Turner, D. and F. Spinelli (2011), "Explaining the Interest-Rate-Growth Differential Underlying Government Debt Dynamics”, OECD Economics Department Working Papers, No. 919, OECD Publishing.

Wheelock, D. and M. Wohar (2009), "Can the Term Spread Predict Output Growth and Recessions? A Survey of the Literature", Federal Reserve Bank of St. Louis Review, September/October Part 1, pp. 419-440.

Yang, J. and K. Tsatsaronis (2012), "Bank Stock Returns, Leverage and the Business Cycle”, BIS Quarterly Review, March. 


\section{WORKING PAPERS}

The full series of Economics Department Working Papers can be consulted at www.oecd.org/eco/workingpapers/

1005. Debt and macroeconomic stability: Debt and the business cycle

(December 2012) by Volker Ziemann

1004. Debt and macroeconomic stability: Case studies

(December 2012) by Rossana Merola

1003. Debt and macroeconomic stability

(December 2012) by Douglas Sutherland, Peter Hoeller, Rossana Merola and Volker Ziemann

1002. Reducing greenhouse gas emissions in a cost effective way in Switzerland.

(December 2012) by Anita Wölfl and Patrizio Sicari

1001. Strengthening innovation in the United States

(November 2012) by David Carey, Christopher Hill and Brian Kahin

1000. Long-term growth scenarios

(forthcoming) by Åsa Johansson, Yvan Guillemette, Fabrice Murtin, David Turner,

Giuseppe Nicoletti, Christine de la Maisonneuve, Philip Bagnoli, Guillaume Bousquet and

Francesca Spinelli

999. Selected aspects of household savings in Germany - evidence from micro-data

(November 2012) by Christina Kolerus, Isabell Koske and Felix Hüfner

998. Improving the tax system in Indonesia

(November 2012) by Jens Arnold

997. Unleashing business innovation in Canada

(November 2012) by Alexandra Bibbee

996. Public policy and resource allocation: evidence from firms in OECD countries

(October 2012) by Dan Andrews and Federico Cingano

995. Promoting SME development in Indonesia

(October 2012) by Annabelle Mourougane

994. Portugal: Rebalancing the economy and returning to growth through job creation and better capital allocation.

(October 2012) by Álvaro Pina and Ildeberta Abreu

993. Public debt, economic growth and nonlinear effects: Myth or reality?

(October 2012) by Balázs Égert

992. Choosing the pace of fiscal consolidation

(September 2012) by Lukasz Rawdanowicz

991. Tertiary education developing skills for innovation and long-term growth in Canada (September 2012) by Calista Cheung, Yvan Guillemette and Shahrzad Mobasher-Fard 
990. Trade and product market policies in upstream sectors and productivity in downstream sectors: firm-level evidence from China

(September 2012) by Maria Bas and Orsetta Causa

989. Intangible assets, resource allocation and growth: a framework for analysis (September 2012) by Dan Andrews and Alain de Serres

988. Current account benchmarks for Turkey

(September 2012) by Oliver Röhn

987. Structural reforms to boost Turkey's long-term growth

(September 2012) by Rauf Gönenç, Oliver Röhn, Vincent Koen and Şeref Saygili

986. Tackling Turkey's external and domestic macroeconomic imbalances

(September 2012) by Oliver Röhn, Rauf Gönenç, Vincent Koen and Ramazan Karaşahin

985. Portugal: Solid foundations for a sustainable fiscal consolidation

(September 2012) by David Haugh and Stéphane Sorbe

984. Portugal: Assessing the risks around the speed of fiscal consolidation in an uncertain environment

(September 2012) by Stéphane Sorbe

983. The German labour market: preparing for the future

(September 2012) by Felix Hüfner and Caroline Klein

982. Climate change policies in Germany: make ambition pay

(September 2012) by Caroline Klein

981. Restarting the growth engine in Finland

(September 2012) by Henrik Braconier

980. Import Competition, Domestic Regulation and Firm-Level Productivity Growth in the OECD (September 2012) by Sarra Ben Yahmed and Sean Dougherty

979. Non-Parametric Stochastic Simulations to Investigate Uncertainty around the OECD Indicator Model Forecasts

(August 2012) by Elena Rusticelli

978. $\quad$ Measuring GDP Forecast Uncertainty using Quantile Regressions

(July 2012) by Thomas Laurent and Tomasz Kozluk

977. Implications of output gap uncertainty in times of crisis

(July 2012) by Romain Bouis, Boris Cournède and Ane Kathrine Christensen

976. Avoiding debt traps: financial backstops and structural reforms

(July 2012) by Pier Carlo Padoan, Urban Sila and Paul van den Noord

975. Sluggish productivity growth in Denmark: the usual suspects?

(July 2012) by Müge Adalet McGowan and Stéphanie Jamet 